\title{
Impact of climate change on the hydrogeology of two basins in Northern France
}

Florence Habets ${ }^{1,2}$, Julien Boé ${ }^{3}$, Michel Déqué ${ }^{4}$, Agnès Ducharne ${ }^{1}$, Simon Gascoin ${ }^{5}$, Ali Hachour $^{2}$, Eric Martin ${ }^{4}$, Christian Pagé ${ }^{5}$, Eric Sauquet ${ }^{6}$, Laurent Terray ${ }^{3}$, Dominique Thiéry $^{7}$, Ludovic Oudin ${ }^{1}$, Pascal Viennot ${ }^{2}$,

${ }^{1}$ UMR Sisyphe 7619, UPMC, CNRS, Paris, France

${ }^{2}$ Centre de Géosciences Mines Paristech, Fontainebleau, France

${ }^{3}$ CERFACS CNRS, Toulouse, France

${ }^{4}$ CNRM/GAME (Météo-France, CNRS), Toulouse, France

${ }^{5}$ CESBIO, Toulouse, France

${ }^{6}$ IRSTEA, Lyon, France

${ }^{7}$ BRGM, Orléans, France

Corresponding author: Florence.Habets@mines-paristech.fr

Abstract

This study presents an analysis of climate change impacts on the water resources of two basins located in Northern France, by integrating four sources of uncertainty: climate modelling, hydrological modelling, downscaling methods, and emission scenarios. The analysis focused on the evolution of the water budget, the river discharges and piezometric heads. Seven hydrological models were used, from lumped rainfall-discharge to distributed hydrogeological models, and led to quite different estimates of the water balance components. One of the hydrological models, CLSM, was found to be unable to simulate the increased water stress and was thus considered as an outlier even though it gave fair results for the present day compared to observations. Although there were large differences in the results between the models, there was a marked tendency towards a decrease of the water resource in the rivers and aquifers (on average in 2050 about $-14 \%$ and $-2.5 \mathrm{~m}$, respectively), associated with global warming and a reduction in annual precipitation (on average in $2050+2.1 \mathrm{~K}$ and $-3 \%$, respectively). The uncertainty associated to climate models was shown to clearly dominate, while the three others were about the same order of magnitude and 3 to 4 times lower. In terms of impact, the results found in this work are rather different from those obtained in a previous study, even though two of the hydrological models and one of the climate models were used in both studies. This emphasizes the need for a survey of the climatic change impact on the water resource.

\section{Introduction}

Global warming is unequivocal (IPCC 2007; Meehl et al., 2007), and is expected to lead to an increase in the use of water for cooling, energy production and 
irrigation, and to increased evapotranspiration (Döll 2002; Parry et al., 2007). This increased water use may be achieved by increased pumping from groundwater, rivers or dams, depending on the availability of the resource, which is also directly affected by climate change. In Europe, increased precipitation is likely to occur in winter in the northern areas, while southern Europe is expected to suffer a decrease in precipitation (Arnell et al., 2001; Christensen et al., 2007). Northern France is located on the border of these two zones and is therefore subject to considerable uncertainty, partly connected with the fact that the precipitation regime is linked to both the large scale circulation and the regional pattern of soil moisture, with a signal that varies depending on the season (Vautard and Yiou, 2010; Boé 2012). These variables have a large spread in the climate projections for Europe (Boé et al., 2009b), as confirmed by the analysis of the ENSEMBLE projections, which used several global and regional climate models over Europe and showed that the uncertainty was associated with both scales (Déqué et al., 2012).

Although it has a mid-latitude oceanic climate, Northern France can suffer from water resource issues, mainly because of the anthropogenic water demand. The high population density (above 200 inhabitants $/ \mathrm{km}^{2}$ ) particularly in the Paris area, together with intensive agriculture (for instance in the Beauce region) and a dense industrial fabric lead to high water demand for drinking, irrigation and cooling. Such pressures affect water resources in terms of quality (Meybeck et al., 1998; Verjus 2008), and in terms of quantity since excessively low groundwater levels have led to restrictions on use in some areas for several years. In such conditions, the evolution of the climate is causing concern about the availability of water resources, especially in the context of regional development, which is tending to increase the population density.

To gain better insight into the impact of climate change on the water resources of the Seine and Somme basins of northern France the RExHySS project included several sources of uncertainty: it used two emissions scenarios, seven climate models, three downscaling methods and seven hydrological models ranging from simple rainfall-discharge models to more complex hydrogeological models. Few previous studies have addressed the uncertainty connected with the combination of emissions scenarios, climate models, downscaling methods and hydrological modelling (Wilby and Harris, 2006; Kay et al., 2009; Görgen et al., 2010; Chen et 
al., 2011; Chen et al., 2012); most studies have used either several downscaling methods but only a single hydrological model (Dibike and Coulibaly, 2005; Khan et al., 2006; Prudhomme and Davies; 2009, Boé et al., 2009; Quintana Seguì et al., 2010), or just one downscaling method with several hydrological models (Ducharne et al., 2007; Bae et al., 2011; Teng et al., 2012).

The first part of this article presents the observed climate data, and the hydrological models, downscaling methods and climate change projections used. Then, the projected climate change in the two basins is presented, together with its impacts on hydrology in terms of water budget, river flows and aquifer levels. The uncertainties associated to the results are then discussed.

\section{Materials and Methods}

\section{Baseline climate data}

The baseline climate data were taken from the SAFRAN analysis (Durand et al., 1993; Quintana Seguì et al., 2008) which provided the solid and liquid precipitation, downward solar and atmospheric radiation, 2-m air temperature and humidity and 10-m wind speed, all at an hourly time step on an 8-km grid. Daily Potential Evapotranspiration (PET) was then computed using the Penman Monteith formula (Monteith, 1965). For the period 1971-2000, the mean annual precipitation is above $900 \mathrm{~mm} / \mathrm{year}$ in the eastern part of the basin and can be lower than $650 \mathrm{~mm} / \mathrm{year}$ in the western part (Figure 1). Precipitation is lower than potential evapotranspiration in $55 \%$ of the domain. Mean annual 2-m temperature varies by only $3 \mathrm{~K}$ throughout the domain, with warmer air in the urbanized areas and in the centre of the basin.

\section{Hydrological models}

To account for the uncertainty associated with the hydrological models, seven models already set up on the basins under study were used in the RExHySS project (Table 1). As the Seine and Somme basins are characterized by the presence of large aquifers that are estimated to account for $40 \%$ and $80 \%$, respectively, of the discharge at the outlets (Rousset et al., 2004; Négrel and Petelet-Giraud, 2005), three of these models explicitly simulate multi-layer aquifer transfer (MARTHE, MODCOU and SIM), three take aquifer storage into 
account with a 1D vertical approach (CLSM, EROS and GARDENIA), and one does not consider the aquifer explicitly (GR4). Two of the hydrological models are based on a soil-vegetation-atmosphere transfer scheme (CLSM and SIM), and thus compute the diurnal evolution of the water and energy budgets instead of using daily PET. Four of the models were applied to both basins, while two models were set up for the Somme basin only, and one for the Seine basin only.

As the hydrological models were already set up in the basins, their calibration period, calibration method and initial conditions differed, preventing the model performance from being attributed to the model structure or calibration practice. However, as the groundwater initial conditions may impact the simulations over several years, a common method was used for the three hydrogeological models: the initial piezometric heads were derived based on a steady simulation that used the mean annual recharge estimated from the first 10 years of the simulation. A brief analysis of the hydrological model results is presented in Table 1 for the main river gauges of the two basins shown in Figure 1. According to the observed discharge availability, different periods were used for the two gauges. All models obtained reasonable results, with a daily efficiency (Nash and Sutcliffe, 1970) above 0.67 and even above 0.8 in $68 \%$ of the cases. However, the bias could be rather large, up to $22 \%$ for MODCOU on the Seine basin. Online resource 1 gives additional insight into the monthly cycle. For the groundwater, an intercomparison study had already been performed on the chalk aquifer of the Somme basin with MARTHE, MODCOU and SIM (Habets et al., 2010). On the 45 wells in common, MARTHE was shown to obtain best results, with a determination coefficient of $71 \%$, while MODCOU and SIM obtained 68 and $67 \%$ respectively, the average biases being $0.88,-0.8$ and $-0.19 \mathrm{~m}$.

\section{Climate models and emission scenarios}

Six time-slice climate projections made during CMIP3 and analysed in AR4 (Meehl et al., 2007) were used. These six projections are based on the A1B emissions scenario (IPCC 2000) and were selected on the basis of an analysis of their climate change impact projected over France and, more precisely, on the most marked change in terms of weather regime and precipitation. In addition to these six global climate models (GCMs), projections from the Arpege climate model (Gibelin et Déqué, 2003) were used. This model was chosen because of its 
finer resolution over France (around $100 \mathrm{~km}$ ) due to the use of a stretched grid. Two of the Arpege projections used different emissions scenarios (A1B and A2) and were only available for the end of the century, and the last one was available continuously from 1950 to 2100 . Such continuous projection is important for hydrological impact studies because it can be used to infer a methodology to initialize the long-term response of the aquifer piezometric head for the time-slice projection.

\section{Downscaling methods}

It is necessary to downscale climate projections to try to reduce their bias and to make them compatible with the finer spatial resolution of the hydrological models (Maraun et al., 2010). In RExHySS, three downscaling methods previously used over France were applied. Two of them, the conventional anomaly method (AN) and the quantile mapping (QM) are based on statistical comparison with local analysis, while the weather typing (WT) method is based on an analysis of large scale circulation. They used the SAFRAN present-day climate data so that the downscaled climate projections reached $8-\mathrm{km}$ spatial resolution. The AN considers that the mean local future climate is shifted but that there is no evolution of the frequency distribution of the variables, which means, for instance, that there is no modification of the precipitation spells (the number of wet days is the same in the future as at present). In our case, the anomalies were computed at the monthly time scale, following the method of Caballero et al. (2007), and considered as additive for the temperature and as multiplicative for the precipitation. The QM was more complex since not simply the mean of the variable but the whole probability density function was corrected, based on a seasonal approach. It was therefore usually applied on regional climate models (Déqué 2007). In order to be able to consider the relationship between the atmospheric variables, the QM was applied to a matrix containing the set of variables and not independently on each time vector variable. The WT (Boé et al., 2007 and 2009) was based on the analysis of the large-scale processes to provide a relationship between the large and regional scales. It considered that similar largescale patterns would lead to similar local-scale patterns. Thus, each day of a given season in the future was taken to have a proxy in the same season of the present-day analysis, and this proxy was used to provide the spatial pattern and 
the diurnal cycle of the given day, with special treatment for the temperature, which was assumed to be significantly warmer in the future.

The three methods allow good consistency to be obtained in the parameter (e.g. a rainy day has humid 2-m air). Only the anomaly method conserves the average impact projected by the GCM. The averaged impact from the other two methods can differ from that of the GCM due to their more sophisticated bias correction, which can modify both the spatial pattern and the range of the impacts. Comparisons of these methods over France as a whole (Boé et al., 2009) and on the Mediterranean part of France (Quintana-Seguì et al., 2010 and 2011) have shown that, although the two most sophisticated methods, QM and WT, gave rather similar results compared to the simple AN one, they could lead to some important local differences on both average and extreme values (more precisely, mean summer temperature and driest summer precipitation).

WT was applied to all climate model runs, while QM and AN were applied only to the finer spatial resolution ARPEGE-V4 model runs. Thus, only the ARPEGEV4 model runs with the A1B and A2 emissions scenarios were downscaled using the three methods (see Table 2). A detailed assessment of the downscaled climate projection for the present day is given in online resource 1 .

\section{Results}

\section{Projected climate change}

Evolutions of the mean precipitation, PET and 2-m air temperature as provided by the 12 downscaled climate projections (DCPs hereafter) for the periods 2047-2067 (2050 hereafter) and 2082-2099 (2080 hereafter) as compared to the present day (1971-2000) on average over the domain are presented Table 2. There is general agreement that the temperature will have increased by $1.7^{\circ}$ to $2.7^{\circ}$ in 2050 , and $2.2^{\circ}$ to $4.2^{\circ}$ in 2080 , and that the PET will have increased by 11 to $22 \%$ by the 2050 s and by 15 to $32 \%$ by around 2080 . There is less agreement on precipitation. On an annual basis, the evolution of precipitation varies by $+0.4 \%$ to $-14 \%$ in 2050 and by $+4 \%$ to $-24 \%$ in 2080 , with only two of the 12 projections predicting an increase in precipitation. There is not much difference between downscaling methods on an annual basis but seasonal differences are more marked (see online 
resource 2).

\section{Impact of climate change on the water budget}

There were a total of 19 DCPs for the two periods and 11 hydrological modelling cases on the two basins, which makes a total of 209 possibilities. However, because of the simulation cost, not all the hydrological models used all the DCPs, and only 147 were effectively available (70\%). The impacts of climate change estimated by these 147 simulations on total runoff are presented in Figure 2 and summarized in Table 3. The main result is a general agreement on a decrease of the total runoff for all the hydrological models and all the downscaled climate projections except the wettest ones (GM in 2080, and G1 in 2050). The average decrease is about $20 \%$ in 2050 and about $30 \%$ in 2080 (Figure 2). However, there is a large spread, which is associated with both the DCPs and the hydrological models. The standard deviation connected with the various DCPs for a given hydrological model ranges from 2 to $19 \%$, and that connected with the various hydrological models for a given GCM ranges from 2 to 27\% (Table 3). Most of the discrepancies on the hydrological models are related to only one of them, CLSM. When CLSM is excluded, the standard deviation is lower than 9\% (Table 3). CLSM is the only hydrological model to project a median decrease of the total runoff larger than $30 \%$ in 2050 and larger than $50 \%$ in 2080 . This is connected with an increase of the median actual evapotranspiration larger than $10 \%$ in the two basins in the future. Indeed, the soil moisture in CLSM is sustained by an upward groundwater flux that almost doubles in the future compared to present days although the ground water level decreases. This, associated to some weaknesses on the management of the soil water stress pointed out in an independent study, may lead to unrealistic results (see online resource 3 for a detailed analysis).

When the average impact of climate change on total runoff without the CLSM model is analysed, it clearly appears that the range associated with DCP (about 0 to $-30 \%$ in 2050 , and about $+4 \%$ to $-40 \%$ for the DCPs using A1B emission in $2080)$ is larger than the range associated with hydrological modelling ( $-10 \%$ to $24 \%$ in 2050 , and about $-23 \%$ to $-48 \%$ in 2080 ). The impact of the downscaling methods is also rather large, with an average impact on the Seine basin in 2080 
varying from $-32 \%$ to $-50 \%$ (Figure 2 and Table 3 ).

\section{Impact on river flows}

Figure 3 presents the monthly anomalies of the Seine and Somme river flows in 2050 and 2080 compared to the present day climate. The sets of DCPs and hydrological models vary for each basin and each period as does the total number of simulations (see caption). The mean monthly anomalies in the Somme basin are around $-20 \%$ in 2050 and $-30 \%$ in 2080 , while in the Seine basin, the decrease is larger in summer $(-30 \%$ in $2050,-40 \%$ in 2080) than in winter $(0 \%$ in 2050 and $-15 \%$ in 2080).

In the Somme basin, about $10 \%$ of the DCPs project almost no change on the annual cycle in both periods (slight increase in winter and slight decrease in summer), while in contrast, $10 \%$ project a decrease of approximately $30 \%$ in 2050 and above $50 \%$ in 2080 throughout the year. The monthly variations are more pronounced in the Seine basin: more than $25 \%$ and $10 \%$ of the DCPs project an increase of the riverflow from February to April in 2050 and 2080 respectively, while $25 \%$ of the simulations project a decrease of the summer discharge by about $30 \%$ and $40 \%$ in 2050 and 2080 respectively. For the 2080 s, $75 \%$ of the simulations project a decrease of the discharge larger than the average decrease projected in the mid-century (Figure 3).

\section{Impact of climate change on piezometric heads}

The piezometric heads in the Seine and Somme basins were simulated by two and four hydrological models respectively. The number of wells simulated varied: 143 wells located on the free part of the aquifer layers for SIM and MODCOU in the Seine basin, and, for the chalk aquifer of the Somme, 57 wells for GARDENIA and MARTHE, and 50 wells for MODCOU and SIM.

The average evolutions of the piezometric head projected by all available DCPs are a diminution of the piezometric by 2.45 and $3.72 \mathrm{~m}$ in the Somme basin in 2050 and 2080, respectively, and by 3.88 and $6.05 \mathrm{~m}$ in the Seine basin (Figure 4, detailed results from the $1 \mathrm{~W}$ continuous simulation are given in online resource 4). The two most contrasted DCPs are $2 \mathrm{~W}$ and GS for the two basins, which is 
consistent with the results obtained on the total runoff. On the Somme basin, for which four hydrological models were available, for a given DCP $(2 \mathrm{~W})$, the largest uncertainty associated with the hydrological model represents $5 \mathrm{~m}$ while, for a given hydrological model, the largest uncertainty reaches $8 \mathrm{~m}$. When the results obtained with the same climate projection but with different downscaling methods are considered, the WT and QM methods reach a variation of 1, 3 and $5 \mathrm{~m}$ for MARTHE, SIM and MODCOU respectively, while the three downscaling methods lead to an uncertainty of $2 \mathrm{~m}$ for GARDENIA, which is the only model used for the three projections. GARDENIA presents the weakest evolution of the piezometric heads for a given DCP. This might be due to the fact that, in a lumped model, the piezometric heads are proportional to the level of a deep reservoir, and neither the evolution of the piezometric head gradient nor the relationship with the river is explicitly considered. The evolution of the piezometric head is more pronounced on the Seine basin than on the Somme basin, which might be due to the selection of the piezometric wells, with more wells located close to the river in the Somme basin. The amplitude of the aquifer decrease is similar to that obtained by Gordeniaux et al. (2011) in a Belgian basin, but larger than the amplitude obtained by Jackson et al. (2011) on a chalk aquifer in England. This could be explained by differences in the evolution of the precipitation.

\section{Discussion}

A detailed analysis was made of the uncertainty with an appropriate statistical method to manage the heterogeneous set of available impact projections (see online resource 5). Not surprisingly, the climate models appear to be the main sources of uncertainty, which is in agreement with the literature since about a decade (see, for instance, Arnell, 1999; Bergstrom et al., 2001; Nissjen et al., 2001). The three other sources of uncertainty, i.e., the ones associated with downscaling methods, emissions scenarios and the hydrological models are about the same range of value and about three times lower than the one associated to the climate modelling, at least when one focuses on the annual discharge, and when only physically sound results were kept. Indeed, it was possible to reduce the uncertainty on the hydrological modelling by considering one model as an outlier for physical reasons, highlighting a good fit with a single observed variable (here, the riverflows) is not sufficient to enable a model to be considered as a suitable 
tool for a projection study. Other sources of uncertainty were, however, neglected in this study. For instance, some physical feedbacks as the impact of the $\mathrm{CO} 2$ on plant transpiration or the modification of direct evaporation from groundwater are not explicitly taken into account by the models. Also, the land use was considered fixed, as was the anthropization of the water resources (no change in pumping pressure) although previous studies have shown their large impact on the water resource (Holman 2006; Candela et al., 2009). Furthermore, the uncertainty associated with the natural variability was not explicitly addressed, although it had a large impact on the discharge of French rivers over the last century, and is recognized as being important in the early decades of climate projections (Hawkins and Sutton 2009; Kay et al., 2009; Terray and Boé 2013). Although this uncertainty analysis is not complete, it nevertheless appears that none of the four sources of uncertainty taken into account can be neglected.

The overall signal obtained in RexHySS is a clear decrease of the water resource of the Seine and Somme basins. This is consistent with the study by Boé et al. (2009), which shares some hydrological projections with RexHySS, but rather different from the one by Ducharne et al. (2007), for which a larger increase of winter flow was compensating the decrease of summer flow to lead to a quite stable annual discharge. Such results were obtained by employing two of the hydrological models used in this study (CLSM and MODCOU) and a former climate projection with the A2 emission scenario. This is the first time that two fairly recent climate change impact studies on a French basin have provided such contrasted results. For instance, the results of Boé et al. (2009) are quite consistent with those obtained in the Rhone and Garonne basins with earlier projections (Etchevers et al., 2001; Caballero et al., 2007). This is perhaps due to the fact that those two basins have a large snow component, for which global warming has quite a clear impact, whereas the Seine basin is hardly affected by snowfall and thus depends on the evolution of the rainfall, which is more uncertain. This reinforces the interest of knowing wether the use of CMIP5 climate projections would lead to similar results. CMIP5 GCMs also project a general tendency for an increase of winter precipitation and a decrease of summer precipitation in northern France (Terray and Boé, 2013). A first comparison of regional climate modelling performed in the framework of the CMIP5 Cordex experiment has shown a larger spread in winter precipitation. However, a full comparison is not yet possible 
because these projections have to be downscaled.

Although the present article does not focus on the extremes, the hydrological extremes projected by RExHySS have been analysed in a companion paper (Ducharne et al., 2011), which reports that the risk of floods returning within 10year and 100-year periods is quite stable.

\section{Conclusion}

This article has attempted to present a full analysis of the impact of climate change on the hydrological component of two basins located in northern France, by including the analysis of surface water and groundwater. A set of 147 hydrological projections based on seven hydrological models, seven climate models, three downscaling methods, and two emissions scenarios was analysed. There is a general agreement on a decrease of the river flow at the outlets of both basins by at least $14 \%$ by the 2050 s and at least $22 \%$ by the 2080 s. More than $90 \%$ of the hydrological projections predict a decrease of the summer flow at the outlets of the Seine and Somme basins (although this is less true for the Somme in the 2080s), and a decline of the piezometric heads for at least $90 \%$ of the wells.

However, the results present a large spread, with a magnitude of the signal on river flow and piezometric head of the same order of magnitude as the standard deviation. About $10 \%$ of the hydrological projections estimated a chance of increased river flow in winter in the Seine and thoughout the year in the Somme, while $10 \%$ projected a decrease of more than $40 \%$ the river discharge at the outlets. The uncertainty on the evolution of the piezometric head seems even larger, since the range of variation can reach $8 \mathrm{~m}$ on average over the simulated piezometers.

The spread is mainly due to the uncertainty associated with the climate projections, especially because of two wetter downscaled climate projections that give an opposite signal on the evolution of the piezometric head and discharge. However, it has been shown that the other three sources of uncertainty taken into account in this study, i.e. the emission scenario, the downscaling method and the hydrological model, are also important, and that other sources of uncertainty as physical feedbacks and natural climate variability were not taken into account.

Therefore, there is a need to make a survey of the impact of climate change in 
such basins. A systematic approach will be helped by the availability of climate services, such as the DRIAS project over France (http://www.drias-climat.fr).

\section{Acknowledgements}

The RExHySS project (Influence du changement climatique sur la ressource en eau et les extrêmes hydrologiques dans les bassins de la Seine et de la Somme) was supported by the research programme "Gestion et Impact du Changement Climatique" of the French Ministère de l'Ecologie et du Développement Durable.

\section{References}

Arnell NW et al. (2001) Hydrology and water resources. In: McCarthy JJ, Canziani O, Leary NA, Dokken DJ, White KS, editors: Climate change impacts, adaptation, and vulnerability. Contribution of Working Group II to the TAR of the IPCC. Cambridge: Cambridge University Press p. 191-233

Arnell N. (1999) The effect of climate change on hydrological regimes in Europe: A continental perspective. Global Environmental Change, 9, 5-23

Bae D-H.; Jung I-W, and Lettenmaier D (2011) Hydrologic uncertainties in climate change from IPCC AR4 GCM simulations of the Chungju Basin, Korea. J Hydrol, 401, 90-105

Bergstrom S, Carlsson B, Gardelin M, Lindstro G, Pettersson A, Rummukainen M (2011) Climate change impacts on runoff in Sweden-assessments by global climate models, dynamical downscaling and hydrological modelling. Climate Research, 16, 101-112

Boé J, Terray L, Habets F, Martin E (2007) Statistical and dynamical downscaling of the Seine basin climate for hydro-meteorological studies. Intern J Climat 7 (12) 1643-1655

Boé J, Terray L, Habets F, Martin E (2009) Projected changes in components of the hydrological cycle in French river basins during the 21st century. Water Resour Res 45 W08426

Boé J, Terray L, Cassou C, Najjac J (2009) Uncertainties in European summer precipitation changes: Role of large scale circulation. Clim Dynam, 33, 265-276

Boé J (2013) Modulation of soil moisture-precipitation interactions over France by large scale circulation. Clim Dynam 40 (3-4) 875-892

Caballero Y et al., (2007) Hydrological sensitivity of the Adour-Garonne river basin to climate change. Wat. Resour. Res., 43 (7) DOI: 10.1029/2005WR004192

Candela L, von Igel W, Javier Elorza F, Aronica G (2009) Impact assessment of combined climate and management scenarios on groundwater resources and associated wetland (Majorca, Spain). J Hydrol, 376, 510-527

Chen J, Brissette F P, Poulin A, Leconte R (2011) Overall uncertainty study of the hydrological impacts of climate change for a Canadian watershed. Water Resour Res, 47, W12509

Chen H, Xu C-Y, Guo S (2012) Comparison and evaluation of multiple GCMs, statistical downscaling and hydrological models in the study of climate change impacts on runoff. J Hydrol, 434-435, 36-45

Christensen J H et al., (2007) Regional Climate Projections. Climate Change 2007: The Physical Science Basis. Contribution of Working Group I to the AR4 of the IPCC Cambridge University Press, Cambridge, United Kingdom and New York, NY, USA

Déqué M (2007) Frequency of precipitation and temperature extremes over France in an anthropogenic scenario: Model results and statistical correction according to observed values. Glob Plan Change, 57, 16-26

Déqué M, Somot S, Sanchez-Gomez E, Goodess CM, Jacob D, Lenderink G (2012) The spread amongst ENSEMBLES regional scenarios: Regional climate models, driving general circulation models and interannual variability. Clim Dynam, 38, 951-964

Dibike YB, Coulibaly P (2005) Hydrologic impact of climate change in the Saguenay watershed: comparison of downscaling methods and hydrologic models. J Hydrol 307, 1-4, 145-163

Döll P, 2002 Impact of climate change and variability on irrigation requirements: A global perspective. Climatic Change 543 269-293 
Ducharne A, et al., (2011). Evolution potentielle du régime des crues de la Seine sous changement climatique. Houille Blanche, 1, 51-57, 37

Ducharne A, et al., (2007) Long term prospective of the Seine river system: Confronting climatic and direct anthropogenic changes. Sci Total Environ 375, 292-311

Durand Y, Brun E, Mérindol L, Guyomarc'h G, Lesaffre B, Martin, E (1993) A meteorological estimation of relevant parameters for snow models. Annals of Glaciology 18 65-71 2238

Etchevers P, Golaz C, Habets F, Noilhan J (2002) Impact of a climate change on the Rhone river catchment hydrology. J Geophys Res A, 107 D16, 4293

Gascoin S, Ducharne A, Carli M, Ribstein P, Habets F (2009) Adaptation of catchment-based land surface model to the hydrogeological setting of the Somme River basin (France). J Hydrol, 368 (1-4), 105-116

Gibelin A-L, Déqué M (2003) Anthropogenic climate change over the Mediterranean region simulated by a global variable resolution model. Climate Dynamics 20 (4) 327-339 doi: 10.1007/s00382-002-0277-1

Goderniaux P, Brouyère S, Blenkinsop S, Burton A, Fowler HJ, Orban P, Dassargues A (2011) Modeling climate change impacts on groundwater resources using transient stochastic climatic scenarios. Water Resour Res, 47, W12516

Görgen K et al., (2010) Assessment of Climate Change Impacts on Discharge in the Rhine River Basin: Results of the RheinBlick2050 Project. CHR report, I-23, 229 pp., Lelystad, ISBN 978-9070980-35-1

Habets F et al., (2008). The SAFRAN-ISBA-MODCOU hydrometeorological model applied over France. J. Geoph. Research, 113, D06113

Habets F et al., (2010) Multi-model comparison of a major flood in the groundwater-fed basin of the Somme River (France). Hydrol Earth Syst Sci, 14[1], 99-117

Hawkins E, Sutton R (2009) The Potential to Narrow Uncertainty in Regional Climate Predictions. BAMS, 90, [8] 1095-1107.

Holman I P (2006) Climate change impacts on groundwater recharge- uncertainty, shortcomings, and the way forward? Hydrogeol.J., 14[5], 637-647

IPCC (2007) Core Writing Team, Pachauri, R.K. Reisinger, A. (Eds.) Contribution of Working Groups I, II and III to the Fourth Assessment Report of the Intergovernmental Panel on Climate Change Geneva, Switzerland. pp 104

IPCC (2000) A Special Report of Working Group III of the Intergovernmental Panel on Climate Change, pp27

Jackson CR, Meister R, Prudhomme C (2011) Modelling the effects of climate change and its uncertainty on UK Chalk groundwater resources from an ensemble of global climate model projections. J Hydrol, 399, 12-28

Kay AL, Davies HN, Bell VA, Jones RG (2009) Comparison of uncertainty sources for climate change impacts: flood frequency in England. Climatic Change 92 41-63

Khan MS, Coulibaly P, Dibike Y (2006) Uncertainty analysis of statistical downscaling methods. J Hydrol, 319 (1-4) 357-382

Korkmaz S, Ledoux E, Önder H (2009) Application of the coupled model to the Somme river basin. J Hydrol, 366 21-34

Ledoux E, et al., (2007) Agriculture and Groundwater Nitrate Contamination in the Seine Basin. The STICS-MODCOU modelling chain. Sci Total Environ 375 33-47

Maraun D, et al., (2010) Precipitation downscaling under climate change: Recent developments to bridge the gap between dynamical models and the end user. Rev Geophys, 48, RG3003

Meehl GA, et al., (2007) Global climate projections, in Climate Change 2007: The Physical Science Basis. Contribution of Working Group I to the AR4 of the IPCC, edited by S. Solomon et al., Cambridge Univ. Press, Cambridge

Meybeck M, de Marsily G, Fustec E (1998) La Seine en son bassin. Fonctionnement écologique d'un système fluvial anthropisé. Paris, France: Elsevier

Nash JE, Sutcliffe JV (1970), River flow forecasting through conceptual models. J Hydrol 10(3), 282-290

Monteith JL (1965) Evaporation and environment. 19th Symposia of the Society for Experimental Biology, University Press, Cambridge, 19:205-234.

Négrel P and Petelet-Giraud E. (2005) Strontium isotopes as tracers of groundwater-induced floods: the Somme case study (France). J Hydrol 305, 99-119,

Nijssen B, O'donnell GM, Hamlet AF, Lettenmaier DP (2001) Hydrologic sensitivity of global rivers to climate change. Climatic Change 50, 143-175 
Parry ML, Canziani OF, Palutikof JP, van der Linden PJ, Hanson CE (2007) Contribution of Working Group II to the AR4 of the IPCC Change Eds. Cambridge University Press, Cambridge, UK, 976 pp

Perrin C, Michel C, Andréassian V (2003) Improvement of a parsimonious model for streamflow simulation. J Hydrol 279(1-4): 275-289

Prudhomme C and Davies H (2009) Assessing uncertainties in climate change impact analyses on the river flow regimes in the UK. Part 2: future climate. Climatic Change 93 197-222

Quintana-Segui P, et al., (2008). The SAFRAN atmospheric analysis: Description and validation. J Appl Meteorol Clim doi: http://dx.doi.org/10.1175/2007JAMC1636.1.

Quintana-Seguì P, Ribes A, Martin E, Habets F, Boé J (2010) Comparison of three downscaling methods in simulating the impact of climate change on the hydrology of Mediterranean basins. $\mathrm{J}$ Hydrol, 383 (1-2) 111-124

Quintana-Seguì P, Habets F, Martin E (2011). Comparison of past and future Mediterranean high and low extremes of precipitation and river flow projected using different statistical downscaling methods. Nat Hazards Earth Syst Sci 11 (5) 1411-1432

Rousset F, et al., (2004) Hydrometeorological modeling of the Seine basin using the SAFRANISBA-MODCOU system. J Geophys Res A 109(D14)

Terray L, Boé J (2013) Quantifying $21^{\text {st }}$-century France climate change and related uncertainties. C R Geoscience 345 136-149.

Teng J, Vaze J, Chiew FHS, Wang B, Perraud JM (2012) Estimating the Relative Uncertainties Sourced from GCMs and Hydrological Models in Modeling Climate Change Impact on Runoff. J Hydrometeor, 13 122-139.

Thiéry D (1990) Logiciel MARTHE. Modélisation d'Aquifère par un maillage Rectangulaire en régime Transitoire pour le calcul hydrodynamique des écoulements, version 4.3. BRGM report, 4S/EAU R32210 1990

Thiéry D (2003) Logiciel GARDENIA version 6.0 - Guide d'utilisation. BRGM report, RP-52832FR, 102 pp., 42

Thiéry D, Moutzopoulos C (1995) Un modèle hydrologique spatialisé pour la simulation de très grands bassins : le modèle EROS formé de grappes de modèles globaux élémentaires. Le Barbé et E. Servat (Ed.) ORSTOM Editions, pp. 285-295.

Vautard R, Yiou P (2009) Control of recent European surface climate change by atmospheric flow. Geophys Res Lett, 36, L22702

Verjus P (2008) Elaboration du SDAGE du bassin Seine Normandie relatif à la gestion de la rareté de la ressource en eau. Houille Blanche DOI: 10.1051/lhb:2008026

Wilby R L, Harris I (2006) A framework for assessing uncertainties in climate change impacts: Low-flow scenarios for the River Thames, UK. Water Resour Res 42 W02419 


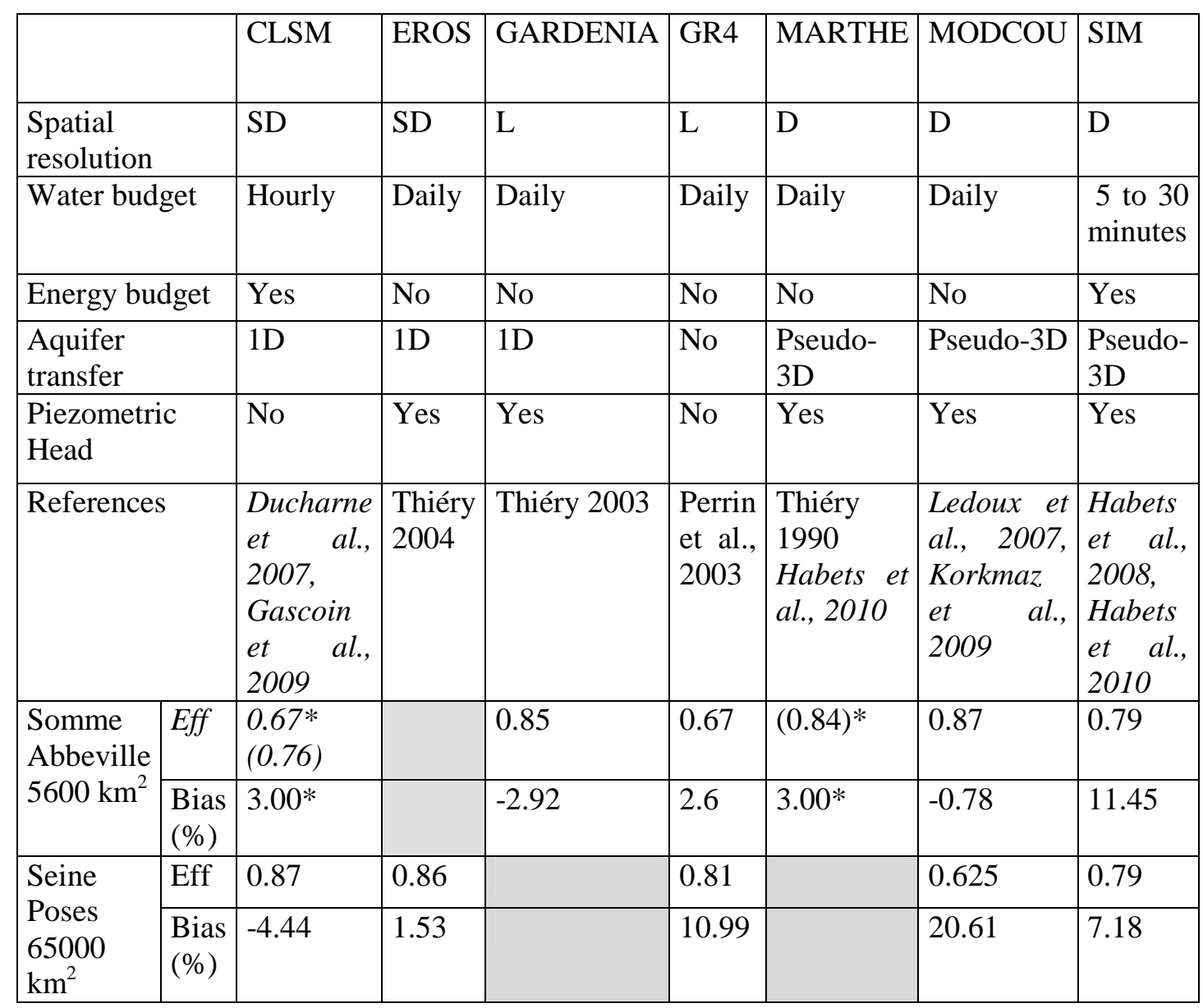

Table 1 Main characteristics of the hydrological model and the statistical results obtained at the two main river gauges of the two basins: SD: semi-distributed, L: Lumped, D: Distributed. References written in italic provide details on the implementation of the model in the basin: Eff is the daily efficiency (Nash and Sutcliffe, 1970) and bias ((1.-Qsim/Qobs)*100.). The time period for the comparison with the observation in the Somme basin is from 25 dec 1985 to 27 Jul 2003 (6400 days), the one in the Seine basin is from 1 Aug 1981 to 31 Jul 2001(6938 days). A* indicates that the period is from $1 / 8 / 1985$ to $31 / 7 / 2003$. The 7-day efficiency is given in parentheses. A grey box indicates that the hydrological model was not applied to the basin in question. 


\begin{tabular}{|c|c|c|c|c|c|c|c|}
\hline \multirow{2}{*}{\multicolumn{2}{|c|}{ AcronymGCM }} & \multicolumn{2}{|c|}{ emissionsdownscaling } & \multicolumn{2}{|r|}{2050} & \multicolumn{2}{|r|}{2080} \\
\hline & & scenarios & method & & & & \\
\hline & & & & $\mathrm{P}$ & PET|T & $P$ & PETT \\
\hline & & A2 & AN & & & & 29.94 .2 \\
\hline $2 \mathrm{~A}$ & ARPEGE-V4 & & & & & 15. & \\
\hline & & A2 & QM & & & & 31.53 .8 \\
\hline $2 Q$ & ARPEGE-V4 & & & & & 23. & \\
\hline & & $\mathrm{A} 2$ & WT & & & & 30.53 .6 \\
\hline $2 \mathrm{~W}$ & ARPEGE-V4 & & & & & 22. & \\
\hline & & A1B & AN & & & & 22.63 .3 \\
\hline $1 \mathrm{~A}$ & ARPEGE-V4 & & & & & 11. & \\
\hline & & A1B & $\mathrm{QM}$ & & & & 25.32 .9 \\
\hline $1 Q$ & ARPEGE-V4 & & & & & 18. & \\
\hline & & A1B & WT & & 19.62 .4 & & 25.9 \\
\hline $1 \mathrm{~W}$ & ARPEGE-V4-CONT & & & 14.0 & & 15. & \\
\hline & & A1B & WT & & 21.92 .7 & & \begin{tabular}{|l|l|}
32.2 & 3.8 \\
\end{tabular} \\
\hline G0 & GFDL_CM2_0 & & & & & 14. & \\
\hline G1 & GFDL_CM2_1 & A1B & WT & -4.7 & 15.71 .7 & -9.5 & 26.23 .0 \\
\hline $\mathrm{EC}$ & ECHAM5/MPI-OM & A1B & WT & 0.4 & 13.12 .2 & -6.8 & 26.03 .5 \\
\hline MR & MRI-CGCM2.3.2 & A1B & WT & -4.5 & 11.31 .9 & -6.3 & \begin{tabular}{|l|l|l|}
3 & 18.92 .6 \\
\end{tabular} \\
\hline GM & GISS-MODEL-ER & A1B & WT & -0.8 & $11.8 \mid 1.7$ & 3.8 & 15.82 .2 \\
\hline$\overline{\mathrm{CC}}$ & CCCMA_GCGM3_1 & $1 \mathrm{~A} 1 \mathrm{~B}$ & WT & -5.8 & 18.02 .5 & -3.2 & 23.93 .2 \\
\hline
\end{tabular}

Table 2: Downscaled climate projection used ant their impacts on the Precipitation (P), Potential evapotranspiration (PET) and 2-m temperature (T) averaged over the Seine and Somme basins for the 2050 s and the 2080 s as projected by the downscaled present day GCM climate. AN: anomaly method, QM: quantile mapping, WT: weather typing. A grey column means that the projection is not available for the period. The acronyms beginning with a number refer to the emissions scenarios (1 for A1B, 2 for A2), while the letter stands for the downscaling method. The other acronyms stand for projections using A1B emission scenario and WT. 


\begin{tabular}{|c|c|c|c|c|c|c|c|c|}
\hline DCPs & \multicolumn{2}{|c|}{ Somme 2050} & \multicolumn{2}{|c|}{ Seine 2050} & \multicolumn{2}{|c|}{ Somme 2080} & \multicolumn{2}{|c|}{ Seine 2080} \\
\hline & All & All but 1 & All & All but 1 & All & All but 1 & All & All but 1 \\
\hline $2 \mathrm{~A}$ & & & & & $-44+/-1$ & Id & $-32+/-6$ & Id \\
\hline $2 Q$ & & & & & $-31+/-7$ & Id & $-37+/-14$ & $-31+/-7$ \\
\hline $2 W$ & & & & & $-65+/-14$ & $-60+/-5$ & $-59+/-15$ & $-50+/-3$ \\
\hline $1 \mathrm{~A}$ & & & & & -40 & Id & $-25+/-4$ & Id \\
\hline $1 Q$ & & & & & $-32+/-5$ & Id & $-33+/-13$ & $-27+/-6$ \\
\hline $1 \mathrm{~W}$ & $-43+/-22$ & $-34+/-5$ & $-32+/-5$ & id & $-43+/-27$ & $-32+/-5$ & $-34+/-6$ & $-34+/-6$ \\
\hline G0 & $-21+/-8$ & Id & $-19+/-14$ & $-13+/-6$ & $-40+/-5$ & Id & $-49+/-19$ & $-40+/-9$ \\
\hline G1 & $0+/-5$ & Id & $-9+/-14$ & $-3+/-7$ & $-5+/-4$ & Id & $-24+/-17$ & $-16+/-6$ \\
\hline EC & $-15+/-5$ & Id & $-12+/-9$ & $-8+/-2$ & $-29+/-6$ & Id & $-34+/-15$ & $-27+/-4$ \\
\hline MR & $-26+/-3$ & Id & $-27+/-7$ & $-24+/-4$ & $-26+/-5$ & Id & $-31+/-10$ & $-27+/-7$ \\
\hline GM & $-1+/-2$ & Id & $-14+/-11$ & $-8+/-3$ & $+4+/-8$ & Id & $-1+/-13$ & $-6+/-3$ \\
\hline $\mathrm{CC}$ & $-23+/-6$ & Id & $-26+/-15$ & $-18+/-5$ & $-20+/-3$ & Id & $-21+/-18$ & $-12+/-5$ \\
\hline $\begin{array}{l}\text { Hydrological } \\
\text { models }\end{array}$ & \multicolumn{2}{|c|}{ Somme 2050} & \multicolumn{2}{|c|}{ Seine 2050} & \multicolumn{2}{|c|}{ Somme 2080} & \multicolumn{2}{|l|}{ Seine 2080} \\
\hline CLSM & \multicolumn{2}{|c|}{-87} & \multicolumn{2}{|c|}{$-36+/-8$} & \multicolumn{2}{|c|}{$-96+/-4$} & \multicolumn{2}{|c|}{$-53+/-17$} \\
\hline EROS & & & \multicolumn{2}{|c|}{$-20+/-11$} & & & \multicolumn{2}{|c|}{$-39+/-2$} \\
\hline GARDENIA & \multicolumn{2}{|c|}{$-23+/-13$} & & & \multicolumn{2}{|c|}{$-48+/-14$} & & \\
\hline GR4 & -19 & & \multicolumn{2}{|c|}{$-10+/-10$} & \multicolumn{2}{|c|}{$-28+/-18$} & \multicolumn{2}{|c|}{$-23+/-14$} \\
\hline MARTHE & \multicolumn{2}{|c|}{-28} & & & \multicolumn{2}{|c|}{$-33+/-15$} & & \\
\hline MODCOU & \multirow{2}{*}{\multicolumn{2}{|c|}{$\frac{-12+/-14}{10+14}$}} & \multicolumn{2}{|c|}{$-15+/-11$} & \multirow{2}{*}{\multicolumn{2}{|c|}{$\frac{-27+/-15}{-29+/-19}$}} & \multicolumn{2}{|c|}{$-24+/-14$} \\
\hline SIM & & & -19 & $/-11$ & & & \multicolumn{2}{|c|}{$-29+/-15$} \\
\hline
\end{tabular}

Table 3 Anomaly on the total runoff in percent estimated for the two basins and the two periods in $\%$. For each downscaled climate projection and hydrological model, the average anomaly $+/-$ the standard deviation computed on the available simulations are given (but the average is not computed from the same number of members). For the DCP, the statistics obtained by all hydrological models except CLSM are also provided (id means identical, no change). 


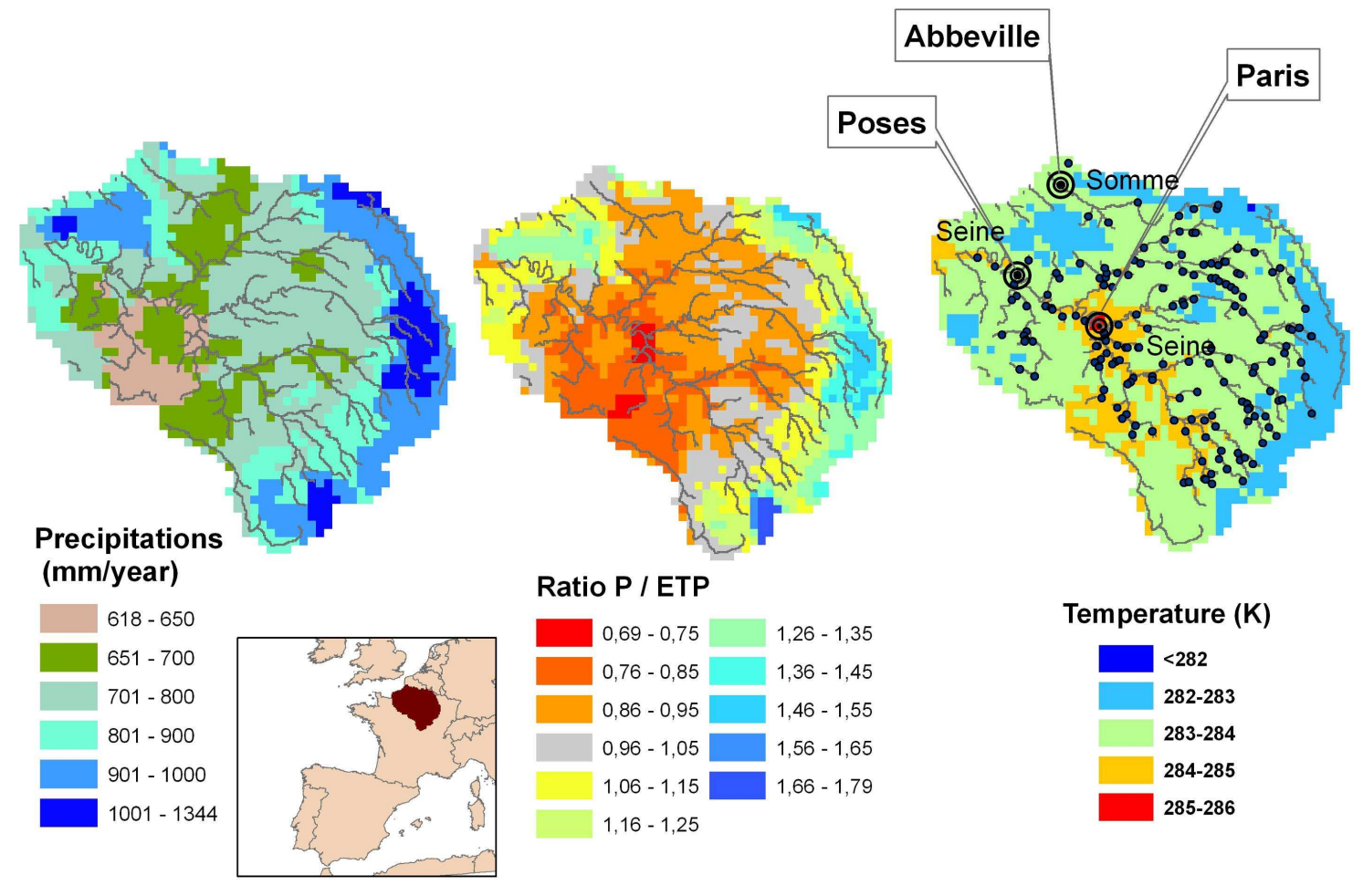

Figure 1 Spatial distribution of the mean annual precipitation (left), ratio of the precipitation to potential evapotranspiration (centre) and 2-m temperature (right) on the domain, as provided by the SAFRAN analysis from 1971 to 2000. 

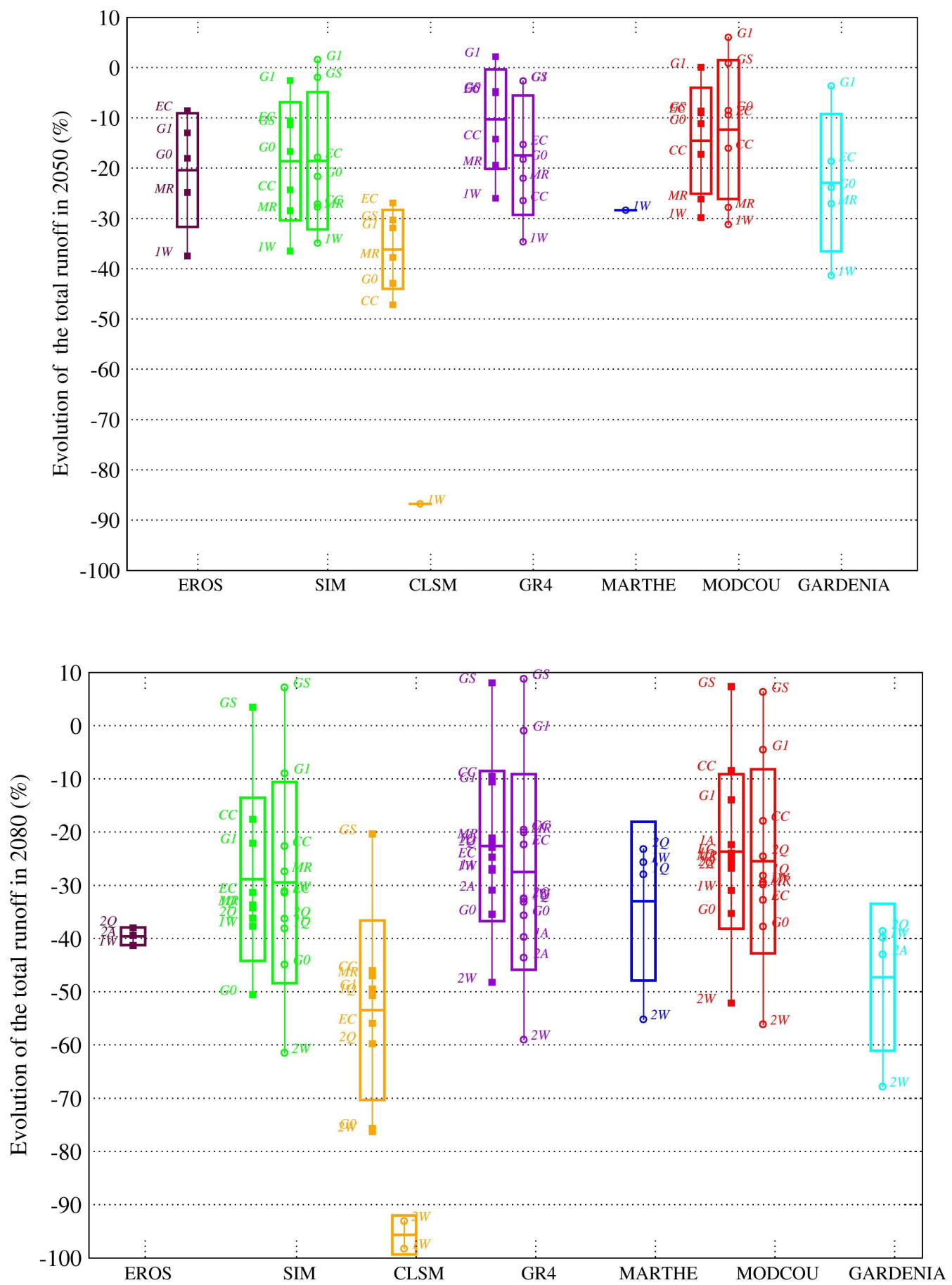

Figure 2 Evolution of the runoff (\%) for mid-century (top) and end-of-century (bottom), for each hydrological model (x-axis) for the Seine basin (circles) and the Somme basin (squares), for each downscaled climate projection. The acronyms of the DCPs are given and, for each model, the boxes indicate the average impact $+/$ - the standard deviation. 

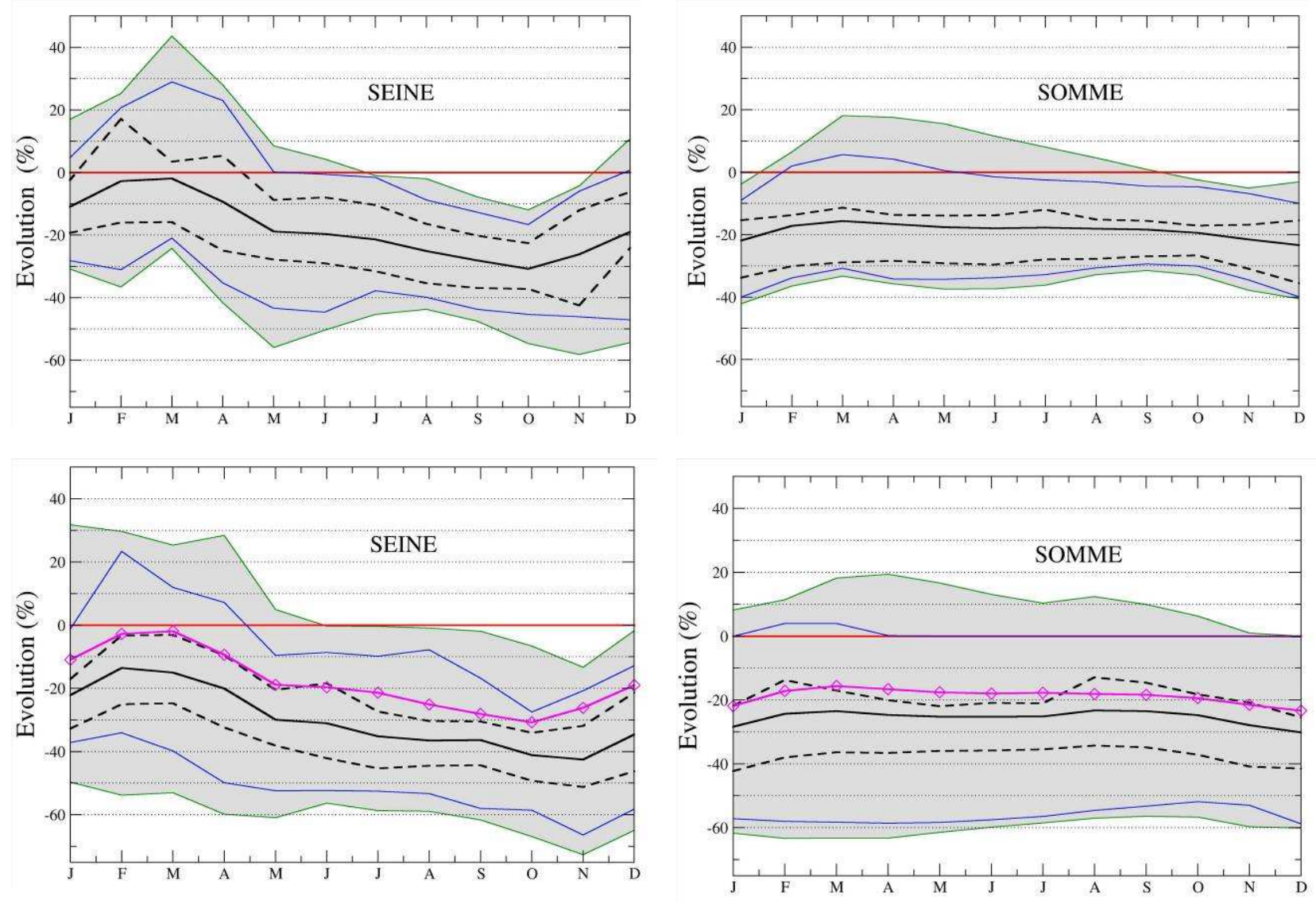

Figure 3 : Monthly evolution of the Seine (left) and Somme (right) river flows for the mid-century (top) and end-of-century (bottom) relative to the simulated present day climate (1971-2000). The envelope represents the minimal and maximal values for each month, the continuous blue thin lines the 10 and 90 quantiles, the dotted lines the 25 and 75 quantiles, and the black line the average. The average in mid-century is plotted at the bottom with pink diamonds. The number of simulations varies on each plot: 36 and 37 for the Seine basin at mid-century and end-of-century, and 26 and 39 respectively for the Somme. 

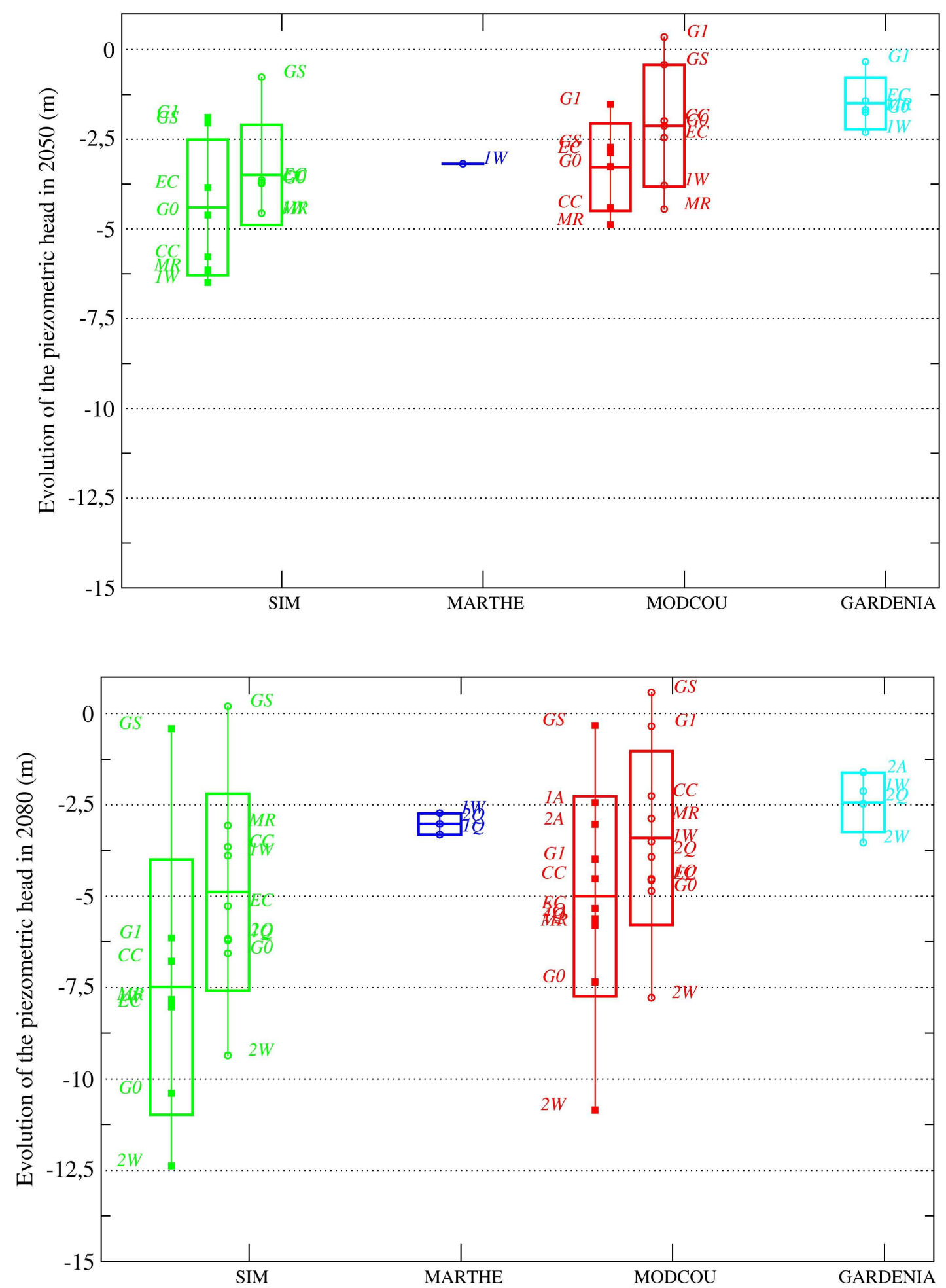

Figure 4 Evolution of the piezometric head (m) on average for each of the simulated wells as projected by the hydrological models for each DCP for the Seine basin (filled squares) and the Somme basin (circles). The acronyms of the DCPs are given, and the boxes indicate the average impact +/- the standard deviation. The upper panel presents the results for the mid-century, and the bottom one the end-of-century. 


\section{Online resource 1}

\section{Impact of climate change on the hydrogeology of two basins in Northern France}

Florence Habets ${ }^{1,2}$, Julien Boé ${ }^{3}$, Michel Déqué ${ }^{4}$, Agnès Ducharne ${ }^{1}$, Simon Gascoin ${ }^{5}$, Ali Hachour $^{2}$, Eric Martin ${ }^{4}$, Christian Pagé ${ }^{5}$, Eric Sauquet ${ }^{6}$, Laurent Terray ${ }^{3}$, Dominique Thiéry $^{7}$, Ludovic Oudin ${ }^{1}$, Pascal Viennot ${ }^{2}$,

${ }^{1}$ UMR Sisyphe 7619, UPMC, CNRS, Paris, France

${ }^{2}$ Centre de Géosciences Mines Paristech, Fontainebleau, France

${ }^{3}$ CERFACS CNRS, Toulouse, France

${ }^{4}$ CNRM/GAME (Météo-France, CNRS), Toulouse, France

${ }^{5}$ CESBIO, Toulouse, France

${ }^{6}$ IRSTEA, Lyon, France

${ }^{7}$ BRGM, Orléans, France

Corresponding author: Florence.Habets@mines-paristech.fr

\section{Evaluation of the downscaled climate modelling in present day}

The comparison of downscaled present day GCM simulations (hereafter DPD) with present day analyses or observations helps to understand some properties of the downscaling methods and characterize some discrepancies associated with the deficiency of these methods or with the uncertainty associated on the natural variability. A DPD is not an atmospheric analysis and is not intented to reproduce the day-to-day meteorology. However, over a 30-year period, the main climate characteristics can be captured by the DPD. This is why in this part the assessment is performed on the mean monthly cycle. By construction, the anomaly method only provides data for the future, so only the Quantile Mapping and Weather Typing present-day projections are assessed, by comparison with the baseline analysis, and when used by the hydrological models.

\section{Comparison with the present day atmospheric analysis.}

Table 4 presents a comparison of the downscaled present-day climate modelling with the SAFRAN analysis over the 30-year period of 1971-2000 for the precipitation, potential evapotranspiration and temperature averaged over the domain. The DPD temperature and PET are quite close to the SAFRAN analysis 
on average, with biases lower than $0.35 \mathrm{~K}$ and $3 \%$, respectively, and a mean monthly correlation close to $100 \%$. Focusing on the precipitation, the mean bias is lower than $1 \%$ for six DPDs out of 10, but reaches $4 \%$ for two DPDs (GM and G1). The correlation computed on the mean monthly cycle reaches $80 \%$ for three DPDs, but is lower than $40 \%$ for two DPDs (G0 and G1). The two downscaling methods applied to the same ARPEGE-V4 simulation (2Q and 2W) show rather contrasted results with biases of $+0.86 \%$ and $-1.57 \%$, and correlations of 54 and $84 \%$ respectively.

\section{Analysis of the hydrological modelling forced by present-day downscaled GCM climate}

The use of the DPDs instead of the baseline forcing analysis by the hydrological models led to some differences in the simulations of the river discharge. Figure 5 and

\begin{tabular}{|c|c|c|c|c|c|c|c|}
\hline \multirow[b]{2}{*}{ Acronym } & \multirow[b]{2}{*}{ nGCM } & \multicolumn{2}{|c|}{ emissionsdownscaling } & \multicolumn{2}{|c|}{2050} & \multicolumn{2}{|c|}{2080} \\
\hline & & scenarios & method & & & & \\
\hline & & & & P & PET|T & $\mathrm{P}$ & PETT \\
\hline & & A2 & AN & & & & 29.94 .2 \\
\hline $2 \mathrm{~A}$ & ARPEGE-V4 & & & & & 15. & \\
\hline & & A2 & QM & & & - & 31.53 .8 \\
\hline $2 \mathrm{Q}$ & ARPEGE-V4 & & & & & 23.7 & \\
\hline & & A2 & WT & & & - & 30.53 .6 \\
\hline $2 \mathrm{~W}$ & ARPEGE-V4 & & & & & 22.2 & \\
\hline & & A1B & AN & & & - & 22.63 .3 \\
\hline $1 \mathrm{~A}$ & ARPEGE-V4 & & & & & 11.8 & \\
\hline & & A1B & QM & & & - & 25.32 .9 \\
\hline $1 \mathrm{Q}$ & ARPEGE-V4 & & & & & 18.0 & \\
\hline & & A1B & WT & & 19.62. & & 25.93 .1 \\
\hline $1 \mathrm{~W}$ & ARPEGE-V4-CONT & & & 14.0 & & 15.5 & \\
\hline & & A1B & WT & -4.3 & 21.92 .7 & - & 32.23 .8 \\
\hline G0 & GFDL_CM2_0 & & & & & 14.2 & \\
\hline G1 & GFDL_CM2_1 & A1B & WT & -4.7 & $15.7 \mid 1.7$ & -9.5 & 26.23 .0 \\
\hline$\overline{\mathrm{EC}}$ & ECHAM5/MPI-OM & A1B & WT & 0.4 & 13.12 .2 & -6.8 & \begin{tabular}{|l|l|l}
326.0 & 3.5 \\
\end{tabular} \\
\hline MR & MRI-CGCM2.3.2 & A1B & WT & -4.5 & $11.3 \mid 1.5$ & -6.3 & \begin{tabular}{|l|l|l|l|}
18.9 & 2.6 \\
\end{tabular} \\
\hline GM & GISS-MODEL-ER & A1B & WT & -0.8 & $11.8 \mid 1.7$ & 3.8 & 15.82 .2 \\
\hline $\mathrm{CC}$ & CCCMA_GCGM3_1 & $1 \mathrm{~A} 1 \mathrm{~B}$ & WT & -5.8 & 18.02 .5 & -3.2 & 23.93 .2 \\
\hline
\end{tabular}


Table 2 : Downscaled climate projection used ant their impacts on the Precipitation (P), Potential evapotranspiration (PET) and 2-m temperature (T) averaged over the Seine and Somme basins for the 2050 s and the 2080s as projected by the downscaled present day GCM climate. AN: anomaly method, QM: quantile mapping, WT: weather typing. A grey column means that the projection is not available for the period. The acronyms beginning with a number refer to the emissions scenarios (1 for A1B, 2 for A2), while the letter stands for the downscaling method. The other acronyms stand for projections using A1B emission scenario and WT. 
present the results for the Seine at Poses compared with the simulations performed with SAFRAN. For GR4, MODCOU and SIM, the DPDs lead to an average $-13 \%$ negative bias on the Seine river flow with a standard deviation of $10 \%$, while they lead to an average positive bias of $5 \% \pm 10$ for EROS. CLSM shows the strongest sensitivity to the DPDs, with an average positive bias of $8 \%$ and a standard deviation of $20 \%$. This large standard deviation is mainly due to the use of the Arpege-V4 simulation downscaled with the Quantile Mapping approach (1Q and 2Q). The reasons for such behaviour are not clear. Although CLSM uses not the daily potential evapotranspiration but the downscaled hourly values of the eight atmospheric variables, this is also the case for SIM, which does not show the same behaviour. Arpege-V4 was also downscaled using the WT method ( $1 \mathrm{~W}$ and $2 \mathrm{~W}$ ). The impact of these two downscaling methods was rather large since, on average over the five hydrological models, the mean annual river flow increased by $13 \%$ for QM and decreased by $14 \%$ for WT. There was more discrepancy in the estimates of the river flow by the hydrological models when they used the forcing of the two downscaling methods applied to the same climate model than when they used the same downscaling method applied to various GCMs. However, the number of cases was too small for a general conclusion to be reached.

From this analysis, it can be said that i) in northern France, the QM and WT downscaling methods applied to present day simulations of climate models lead to atmospheric forcings that are suitable for use by hydrological models to infer annual river flow close to the one simulated using baseline meteorological forcing and also close to observations ii) The hydrological models are obviously sensitive to these DPDs, but they do not react in the same way. The discrepancy is considerable even for similar hydrological model types (lumped, distributed, with or without explicit representation of groundwater) and iii) the downscaling methods can lead to notable differences in the DPDs, which are probably linked to the natural variability of the climate model as shown by Terray and Boé (2013) by analysing the various member of the CMIP5 climate models over France.

References:

Terray L, Boé J (2013) Quantifying $21^{\text {st }}$-century France climate change and related uncertainties. C.R. Geoscience 345 136-149. 


\begin{tabular}{|c|c|c|c|c|c|c|c|c|c|c|}
\hline \multirow{2}{*}{ Acronym } & \multirow{2}{*}{ nGCM } & \multirow{2}{*}{$\begin{array}{l}\text { Emissions } \\
\text { scenarios }\end{array}$} & \multicolumn{4}{|c|}{ DM 20502010P } & \multicolumn{2}{|l|}{ PET } & \multicolumn{2}{|l|}{$T$} \\
\hline & & & & & $\begin{array}{l}\text { Bias } \\
\%\end{array}$ & Cor & $\begin{array}{l}\text { Bias } \\
\%\end{array}$ & Cor & Bias & Cor \\
\hline $2 \mathbf{A}$ & ARPEGE-V4 & A2 & $\mathbf{A N}$ & $\mathbf{Y}$ & & & & & & \\
\hline $2 Q$ & ARPEGE-V4 & A2 & $\mathbf{Q M}$ & $\mathbf{Y}$ & 0.86 & 0.54 & $4-2.71$ & 1.0 & 0.17 & 1.0 \\
\hline $2 W$ & ARPEGE-V4 & A2 & WT & $\mathbf{Y}$ & -1.57 & 0.84 & 42.71 & 0.99 & 0.27 & 1.0 \\
\hline $\mathbf{1 A}$ & ARPEGE-V4 & A1B & $\mathbf{A N}$ & $\mathbf{Y}$ & & & & & & \\
\hline 1Q & ARPEGE-V4 & A1B & $\mathbf{Q M}$ & $\mathbf{Y}$ & 0.86 & 0.54 & $4-2.71$ & 1.0 & 0.17 & 1.0 \\
\hline $1 \mathrm{~W}$ & ARPEGE-V4-CONT & A1B & WT Y & $\mathbf{Y}$ & -1.28 & 0.77 & 72.78 & 0.99 & 0.26 & 1.0 \\
\hline G0 & GFDL_CM2_0 & A1B & WT Y & $\mathbf{Y}$ & -0.13 & 0.39 & 92.01 & 0.99 & 0.29 & 0.99 \\
\hline G1 & GFDL_CM2_1 & A1B & WT Y & $\mathbf{Y}$ & -5.17 & 0.34 & 41.07 & 0.99 & 0.14 & 1.0 \\
\hline $\mathbf{E C}$ & ECHAM5/MPI-OM & A1B & WT Y & $\mathbf{Y}$ & -0.97 & 0.81 & 11.71 & 0.99 & 0.20 & 1.0 \\
\hline MR & MRI-CGCM2.3.2 & A1B & WT Y & $\mathbf{Y}$ & -0.66 & 0.74 & 41.62 & 0.99 & 0.34 & 1.0 \\
\hline GM & GISS-MODEL-ER & A1B & WT Y & $\mathbf{Y}$ & -4.43 & 0.84 & 42.52 & 0.99 & 0.28 & 1.0 \\
\hline $\mathbf{C C}$ & CCCMA_GCGM3_1 & A1B & WT Y & $\mathbf{Y}$ & -0.45 & 0.67 & 72.20 & 0.99 & 0.18 & 1.0 \\
\hline & SAFRAN & & & & $\begin{array}{l}2.18 \\
\mathrm{~mm} / \mathrm{c}\end{array}$ & & $\begin{array}{l}2.14 \\
\mathrm{~mm} / \mathrm{c}\end{array}$ & & $\begin{array}{l}283 . \\
\mathrm{K}\end{array}$ & \\
\hline
\end{tabular}

Table 4 Precipitation (P), Potential evapotranspiration (PET) and 2-m temperature (T) averaged over the Seine and Somme basins for 1971-2000 for the SAFRAN analysis and the downscaled present day GCM climate. Cor stands for correlation (cor $=\frac{\sigma_{\text {SAFRAN,GCM }}}{\sigma_{\text {SAFRAN }} \sigma_{G M}}$, with $\sigma$ the covariance) which was computed on the mean monthly cycle. DM: downscaling method, AN: anomaly method, QM: quantile mapping, WT: weather typing. $Y$ in the 2050 s and 2080 s columns indicates the availability of the climate projection for the period. 


\begin{tabular}{|l|l|l|l|l|l|l|l|}
\hline $\begin{array}{l}\text { Downscaled } \\
\text { GCM }\end{array}$ & CLSM & EROS & GR4 & MODCOU & SIM & Average & $\begin{array}{l}\text { Standard } \\
\text { deviation }\end{array}$ \\
\hline $\mathbf{2 A}$ & & & & & & & \\
\hline $\mathbf{2 Q}$ & 46.5 & 5.3 & 5 & 6 & 2.7 & $\mathbf{1 3 . 1}$ & $\mathbf{1 8 . 7}$ \\
\hline $\mathbf{2 W}$ & -3.1 & -17 & -15.7 & -15.4 & -19.6 & $\mathbf{- 1 4 . 2}$ & $\mathbf{6 . 4}$ \\
\hline $\mathbf{1 A}$ & & & & & & & \\
\hline $\mathbf{1 Q}$ & 46.5 & 5.3 & 5 & 6 & 2.7 & $\mathbf{1 3 . 1}$ & $\mathbf{1 8 . 7}$ \\
\hline $\mathbf{1 W}$ & -3.6 & 11.0 & -17.3 & -17 & -19.5 & $\mathbf{- 9 . 3}$ & $\mathbf{1 3 . 0}$ \\
\hline G0 & 8.3 & 11.9 & -15.9 & -16.1 & -13.6 & $\mathbf{- 5 . 1}$ & $\mathbf{1 4 . 0}$ \\
\hline G1 & -6.1 & 0.6 & -25.9 & -25.6 & -24.6 & $\mathbf{- 1 6 . 3}$ & $\mathbf{1 2 . 6}$ \\
\hline EC & 0.7 & 10.8 & -15.9 & -17.7 & -16.8 & $\mathbf{- 7 . 8}$ & $\mathbf{1 2 . 9}$ \\
\hline MR & 2 & 14 & -13.8 & -12.5 & -14.3 & $-\mathbf{4 . 9}$ & $\mathbf{1 2 . 6}$ \\
\hline GM & -7.5 & & -22.4 & -22.9 & -23 & $\mathbf{- 1 9 . 0}$ & $\mathbf{7 . 6}$ \\
\hline CC & -0.4 & & -17.1 & -18.7 & -19.2 & $\mathbf{- 1 3 . 9}$ & $\mathbf{9 . 0}$ \\
\hline Average & $\mathbf{8 . 3}$ & $\mathbf{5 . 2}$ & $\mathbf{- 1 3 . 4}$ & $\mathbf{- 1 3 . 4}$ & $\mathbf{- 1 4 . 5}$ & & \\
\hline $\begin{array}{l}\text { Standard } \\
\text { deviation }\end{array}$ & $\mathbf{2 0 . 6}$ & $\mathbf{1 0 . 0}$ & $\mathbf{1 0 . 3}$ & $\mathbf{1 0 . 9}$ & $\mathbf{9 . 7}$ & & \\
\hline $\begin{array}{l}\text { SAFRAN } \\
\text { (m3/s) }\end{array}$ & $\mathbf{4 8 8 . 8}$ & $\mathbf{5 1 8 . 6}$ & $\mathbf{5 6 6 . 9}$ & $\mathbf{6 1 5 . 1}$ & $\mathbf{5 4 7 . 2}$ & & \\
\hline
\end{tabular}

Table 5 Difference $(\%)$ between the Seine river flows at Poses computed by the hydrological model forced by the downscaled present-day GCM climate for the period 1970-2000 and the flows computed by the model forced by the SAFRAN analysis over the 1971-2001 period (the reference value is provided in the SAFRAN line, in $\mathrm{m}^{3} / \mathrm{s}$ ). Last two columns: average and standard deviation associated with each downscaled present-day GCM climate. Last two lines: average and standard deviation associated with each hydrological model. 

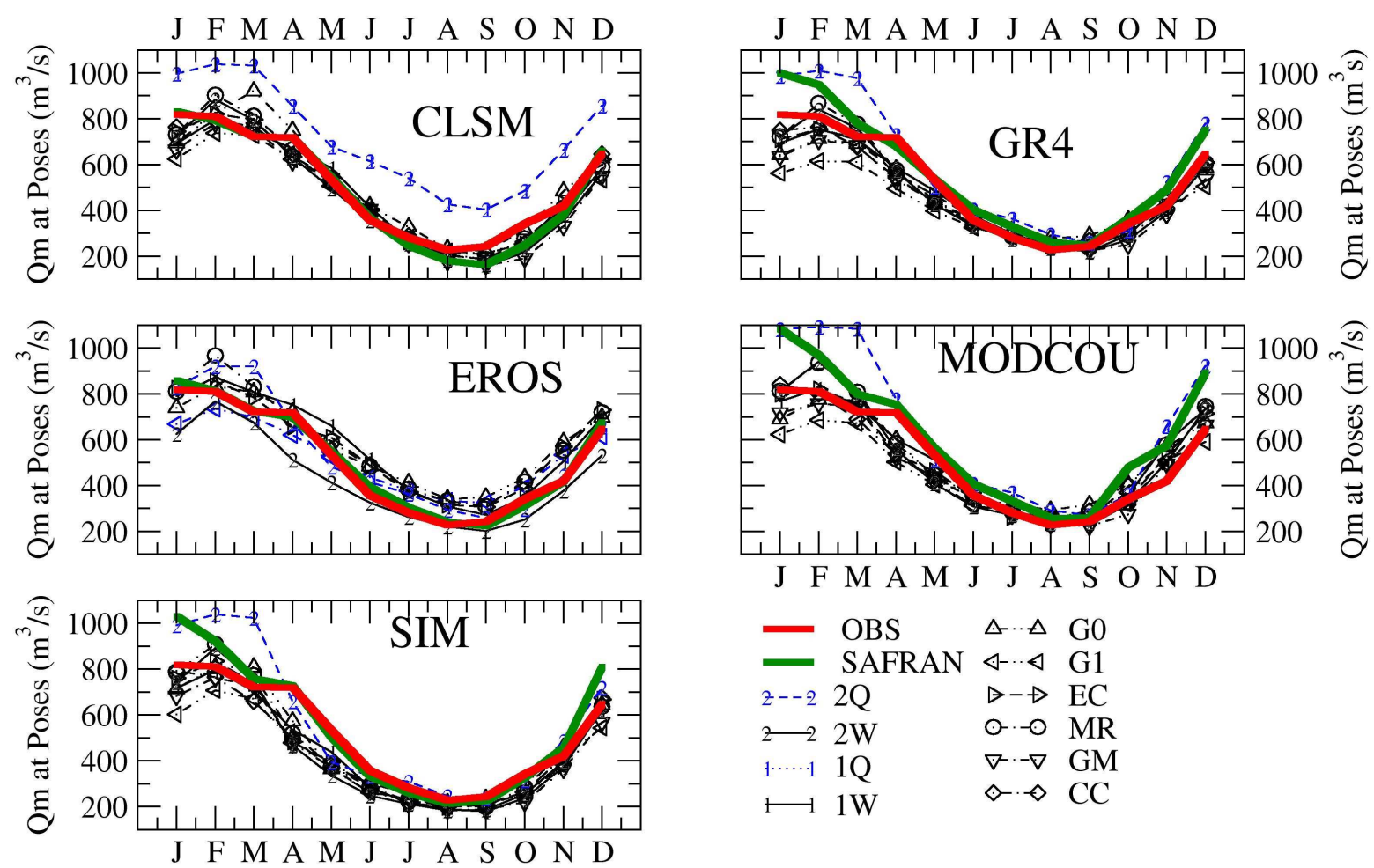

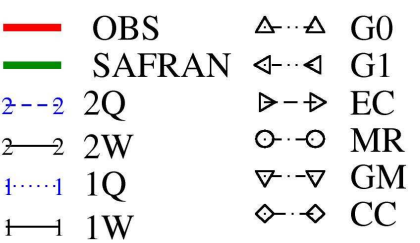

Figure 5 Monthly river flows of the Seine at Poses $\left(\mathrm{m}^{3} / \mathrm{s}\right)$ observed (thick red line) and simulated by the hydrological models using the SAFRAN analysis (thick green line) over the 1971-2001 period, and simulated by the hydrological models forced by the downscaled present-day GCM climate for the 1970-2000 (symbol lines), downscaled with either QM (blue lines) or WT (black lines). 


\section{Online resource 2: \\ Impact of climate change on the hydrogeology of two basins in Northern France}

Florence Habets ${ }^{1,2}$, Julien Boé ${ }^{3}$, Michel Déqué ${ }^{4}$, Agnès Ducharne ${ }^{1}$, Simon Gascoin ${ }^{5}$, Ali Hachour $^{2}$, Eric Martin ${ }^{4}$ Christian Pagé, Eric Sauquet ${ }^{6}$, Laurent Terray ${ }^{3}$, Dominique Thiéry $^{7}$, Ludovic Oudin ${ }^{1}$, Pascal Viennot ${ }^{2}$,

${ }^{1}$ UMR Sisyphe 7619, UPMC, CNRS, Paris, France

${ }^{2}$ Centre de Géosciences Mines Paristech, Fontainebleau, France

${ }^{3}$ CERFACS CNRS, Toulouse, France

${ }^{4}$ CNRM/GAME (Météo-France, CNRS), Toulouse, France

${ }^{5}$ CESBIO, Toulouse, France

${ }^{6}$ IRSTEA, Lyon, France

${ }^{7}$ BRGM, Orléans, France

Corresponding author: Florence.Habets@mines-paristech.fr

\section{Projected climate change}

Figure 6 presents the evolution of the seasonal and annual precipitation, PET and 2-m air temperature as projected by the 12 downscaled climate projections for 2050 and 2080. There is a trend towards decreasing precipitation in summer and autumn, but no clear signal in winter and spring. The difference between downscaling methods is exacerbated on the summer temperature for the ARPEGE-V4 A2 projection (Figure 6), for which the AN and QM provide an average increase of $6^{\circ}$ in 2080, while WT only gives a $4^{\circ}$ increase. Another difference that might have an important impact on the hydrology is the evolution of the precipitation in winter. While AN and QM lead to weak decreases $(-1.5 \%$ and $-6 \%$ respectively), WT leads to a larger decrease $(-16 \%)$. 

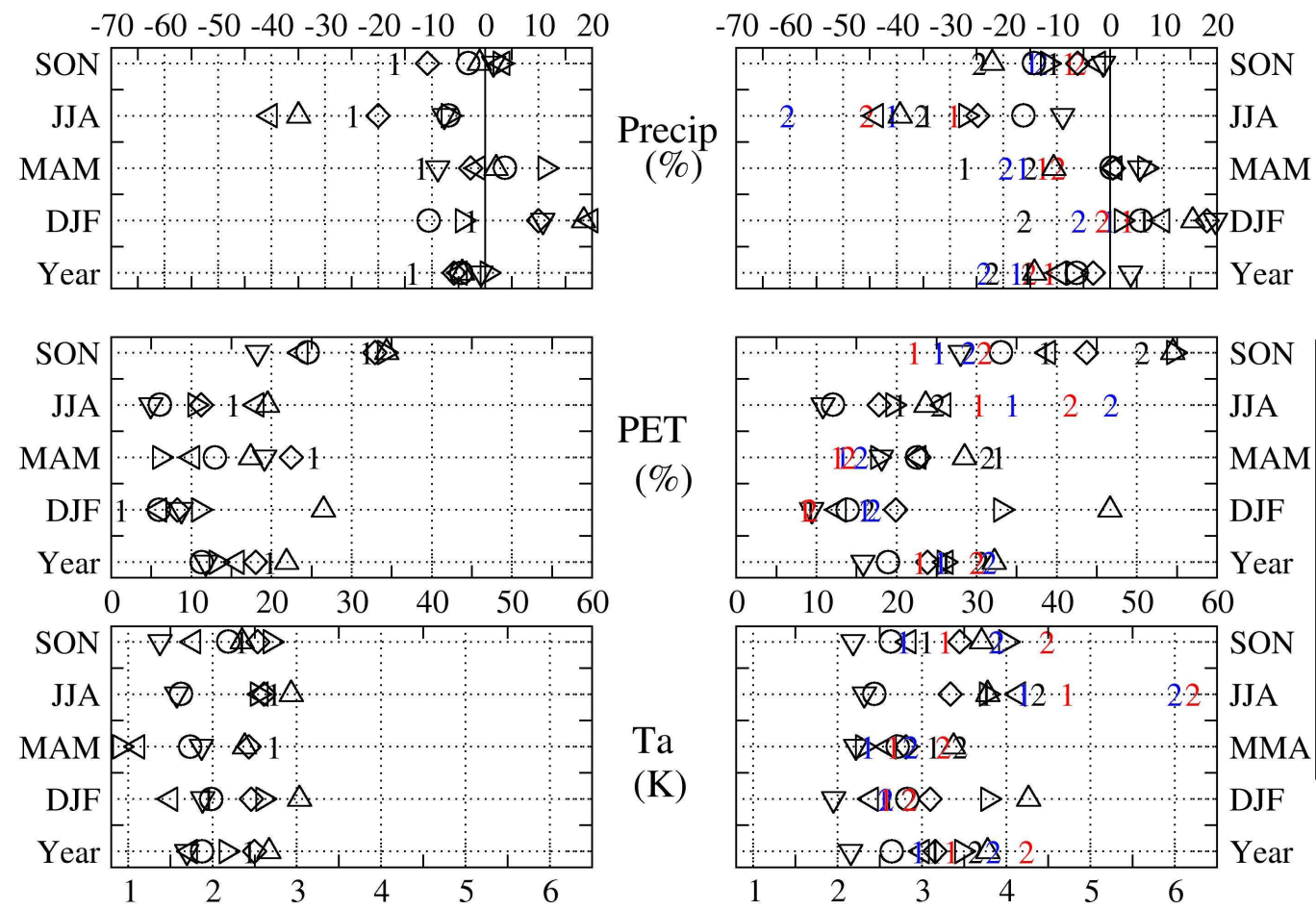

PET

$(\%)$
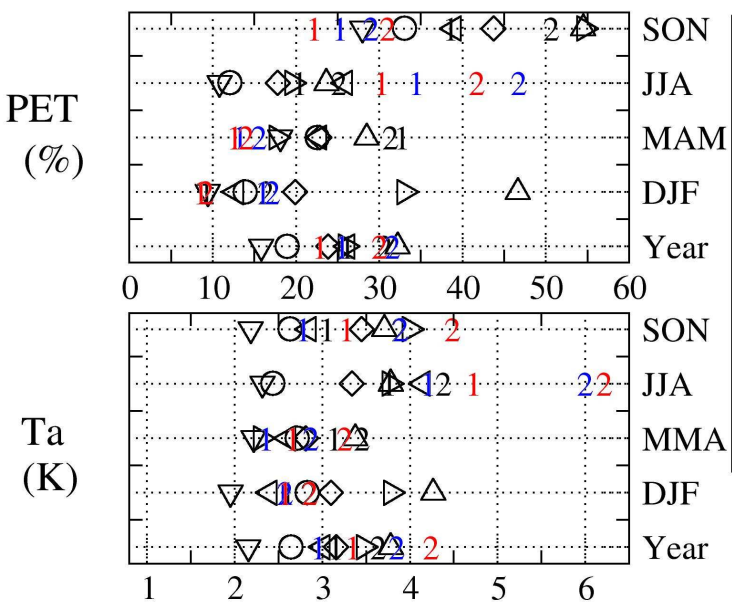

\begin{tabular}{|ll}
\hline 2 & $2 \mathrm{~A}$ \\
2 & $2 \mathrm{Q}$ \\
2 & $2 \mathrm{~W}$ \\
1 & $1 \mathrm{~A}$ \\
1 & $1 \mathrm{Q}$ \\
1 & $1 \mathrm{~W}$ \\
$\diamond$ & $\mathrm{CC}$ \\
$\triangle$ & $\mathrm{G} 0$ \\
$\triangleleft$ & $\mathrm{G} 1$ \\
$\nabla$ & $\mathrm{GM}$ \\
$\triangleright$ & $\mathrm{EC}$ \\
$\bigcirc$ & $\mathrm{MR}$ \\
\hline
\end{tabular}

Figure 6 Seasonal and annual evolutions of the precipitation (\%, top), potential evapotranspiration $(\%$, middle) and $2-\mathrm{m}$ air temperature $(\mathrm{K}$, bottom) as projected by the downscaled climate projections for around 2050 (2047-2065 versus 1971-2000, left), and 2080 (2082-2099 versus 1971-2000, right). The symbols correspond to the DCPs, those downscaled with WT in black, with QM in blue, and with AN in red. 


\section{Online resource 3}

\section{Impact of climate change on the hydrogeology of two basins in Northern France}

Florence Habets ${ }^{1,2}$, Julien Boé ${ }^{3}$, Michel Déqué ${ }^{4}$, Agnès Ducharne ${ }^{1}$, Simon Gascoin ${ }^{5}$, Ali Hachour ${ }^{2}$, Eric Martin ${ }^{4}$, Christian Pagé ${ }^{5}$, Eric Sauquet ${ }^{6}$, Laurent Terray ${ }^{3}$, Dominique Thiéry $^{7}$, Ludovic Oudin ${ }^{1}$, Pascal Viennot ${ }^{2}$,

${ }^{1}$ UMR Sisyphe 7619, UPMC, CNRS, Paris, France

${ }^{2}$ Centre de Géosciences Mines Paristech, Fontainebleau, France

${ }^{3}$ CERFACS CNRS, Toulouse, France

${ }^{4}$ CNRM/GAME (Météo-France, CNRS), Toulouse, France

${ }^{5}$ CESBIO, Toulouse, France

${ }^{6}$ IRSTEA, Lyon, France

${ }^{7}$ BRGM, Orléans, France

Corresponding author: Florence.Habets@mines-paristech.fr

\section{Impact of climate change on the water balance}

Figure 7 presents the evolution of the mean actual evaporation for each period as simulated by each hydrological model forced by the DCPs. In the 2050's, the median evolution of the actual evaporation is close to zero for each hydrological model except MODCOU (-5\%) and CLSM (above +10\%). In the 2080's, all the hydrological models estimate a median decrease of the actual evaporation by 5 to $15 \%$ except CLSM which estimates an increase by more than 10\%. CLSM thus appears as an outlier model here.

To investigate the source of such dispersion, a thorough analysis was performed. Monthly evolutions of the actual evapotranspiration, variation of soil moisture and river flow at the outlet of the Seine basin (Poses) according to four hydrological models for the present day, 2050 and 2080 are plotted in Figure 8. In the present day (black lines), although the mean total runoff is similar for all the hydrological models, the other two variables show more discrepancies: the maximum value of the monthly evapotranspiration ranges from 2 to $3 \mathrm{~mm} /$ day, and the annual amplitude of the monthly soil water storage ranges from 1 to $4 \mathrm{~mm} / \mathrm{day}$. This is because the hydrological models only use the river discharge as a control variable, and do not (or cannot) assess the other terms of the water budget. But, as already 
pointed out by previous studies, the uncertainty on the soil moisture or on evaporation in the present day leads to larger uncertainty in the future (Bergstrom et al., 2001, Douville et al., 2002, Boé and Terray 2008, Severinatne et al., 2010).

In the 2050s and 2080s, the increase in atmospheric water demand leads to an increase in actual evapotranspiration in spring, which is associated with a faster decrease of the soil water storage. This increases the water stress, which, in turn, leads to a decrease of the actual evapotranspiration in summer time. This is true for all models except CLSM, for which actual evapotranspiration is sustained by a larger depletion of the soil moisture (about twice the present day value), with dramatic consequences on the river flow. Indeed, CLSM is able to mobilize a larger soil water resource, partly due to an upward flux from the groundwater which almost doubles from present day to future day $(0.2 \mathrm{~mm} / \mathrm{d}$ to about 0.36 $\mathrm{mm} / \mathrm{d}$ on average over the whole basin). Upward water flux from groundwater to surface can be effective when the saturated zone is shallow (Miguez-Macho et al., 2007, Kollet 2009). However, this is not the case for most of the Seine groundwater bodies. Moreover, according to hydrogeological simulations, such fraction is projected to decrease. For instance, for MODCOU about $18 \%$ of the Seine basin has an aquifer lying within $5 \mathrm{~m}$ of depth in present day, and about $14 \%$ in the 2050s. Thus, the results of CLSM are probably unrealistic, and a previous independent study has pointed out that the model shows some weaknesses in managing soil water stress.

Therefore, it is very likely that the spread induced by this hydrological model can be classified as a "bad source of uncertainty", i.e. closer to a wrong simulation of the physical processes than to a real source of uncertainty.

\section{References:}

Bergstrom S, Carlsson B, Gardelin M, Lindstro G, Pettersson A, Rummukainen M (2011) Climate change impacts on runoff in Sweden-assessments by global climate models, dynamical downscaling and hydrological modelling. Climate Research, 16, 101-112

Boé J. and Terray L. (2008) Uncertainties in summer evapotranspiration changes over Europe and implications for regional climate change GRL, 35

Douville H, Chauvin F, Planton S, Royer JF, Salas-Mélia D, Tyteca S (2002) Sensitivity of the hydrological cycle to increasing amounts of greenhouse gases and aerosols. Clim Dynam, 20, 4568

Kollet S. (2009) Influence of soil heterogeneity on evapotranspiration under shallow water table conditions:

transient, stochastic simulations. Environ Res Lett 4035007 
Miguez-Macho G, Fan Y, Weaver CP, Walko R, and Robock A (2007) Incorporating water table dynamics in climate modeling: 2. Formulation, validation, and soil moisture simulation. J Geophys Res, 112, D13108, doi:10.1029/2006JD008112.

Seneviratne SI, Corti T, Davin EL, Hirschi M, Jaeger EB, Lehner I, Orlowsky B, Teuling AJ (2010) Investigating soil moisture-climate interactions in a changing climate: A review. EarthScience Reviews 99, 125-161 

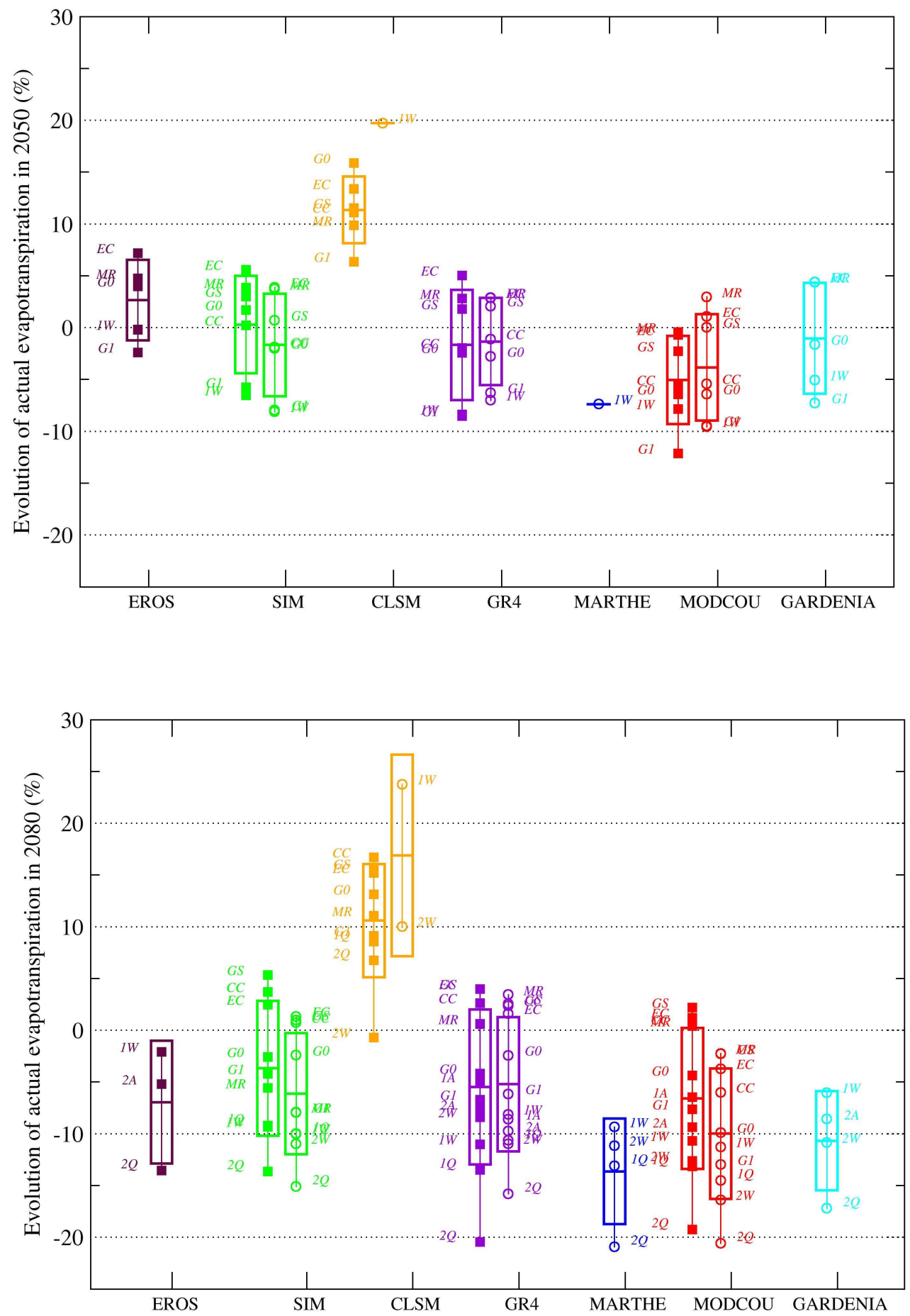

Figure 7 Evolution of the actual evapotranspiration (\%) for mid-century (top) and end-of-century (bottom), for each hydrological model (x-axis) for the Seine basin (empty circles) and the Somme basin (filled squares), for each downscaled climate projection. The acronyms of the DCPs are given and, for each hydrological model, the box represents the average impact $+/-$ the standard deviation. 


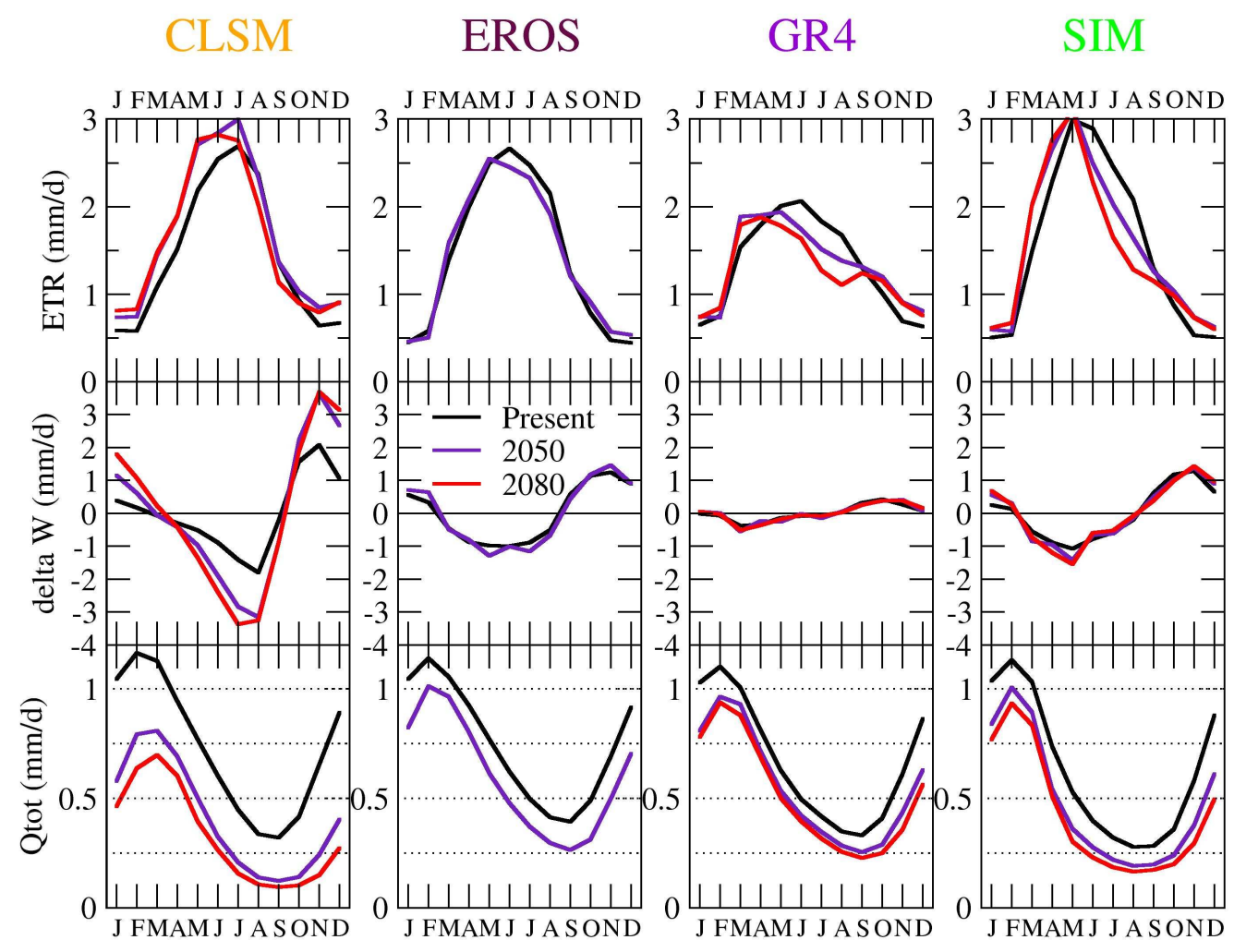

Figure 8 Monthly actual evapotranspiration (top), evolution of the soil water storage (middle) and total runoff (bottom) estimated by four hydrological models on the Seine basin, on average on present day (black), mid-century (blue) and at end of century (red). The unit for each plot is $\mathrm{mm} / \mathrm{d}$. 


\section{Online resource 4: Impact of climate change on the hydrogeology of two basins in Northern France}

Florence Habets ${ }^{1,2}$, Julien Boé ${ }^{3}$, Michel Déqué ${ }^{4}$, Agnès Ducharne ${ }^{1}$, Simon Gascoin ${ }^{5}$, Ali Hachour ${ }^{2}$, Eric Martin ${ }^{4}$, Christian Pagé ${ }^{5}$, Eric Sauquet ${ }^{6}$, Laurent Terray ${ }^{3}$, Dominique Thiéry $^{7}$, Ludovic Oudin ${ }^{1}$, Pascal Viennot ${ }^{2}$,

${ }^{1}$ UMR Sisyphe 7619, UPMC, CNRS, Paris, France

${ }^{2}$ Centre de Géosciences Mines Paristech, Fontainebleau, France

${ }^{3}$ CERFACS CNRS, Toulouse, France

${ }^{4}$ CNRM/GAME (Météo-France, CNRS), Toulouse, France

${ }^{5}$ CESBIO, Toulouse, France

${ }^{6}$ IRSTEA, Lyon, France

${ }^{7}$ BRGM, Orléans, France

Corresponding author: Florence.Habets@mines-paristech.fr

\section{Impact of climate change on the piezometric head of the continuous climate projection}

Figure 9 presents the evolution of the piezometric heads, on average and for the quantiles 10, 25, 75 and 90, as projected using the $1 \mathrm{~W}$ continuous simulation relative to the mean computed over the period 1971-2000. The piezometric head shows a decreasing trend, which is more marked for the Seine basin (about $6 \mathrm{~m}$ on average for MODCOU to $7 \mathrm{~m}$ for SIM at the end of the century) than for the Somme basin (about $2 \mathrm{~m}$ on average for GARDENIA to $4 \mathrm{~m}$ in SIM). However, there is a large difference in the well responses: in both basins, about $10 \%$ of the wells show almost no variation (these wells are low in the valley, close to the river). In the Somme basin, a 5-m decrease of the piezometric head is predicted on $25 \%$ of the wells by all models except GARDENIA (for which this threshold is reached by more than $10 \%$ of the wells) and a $10-\mathrm{m}$ decrease is predicted for $10 \%$ of the wells in MOCOU and SIM at the end of the century (these wells being located on the plateaux). In the Seine basin, a 10-m decrease is predicted for $10 \%$ of the wells by MODCOU and for more than $25 \%$ of the wells as early as midcentury by SIM. As SIM and MODCOU share the same modelling of the 
groundwater transfer, this difference is due purely to the estimation of the water budget since the actual evapotranspiration is projected to undergo a larger decrease in MODCOU than in SIM, thus limiting the decrease of the aquifer recharge in MODCOU compared to SIM.

GARDENIA SOMME

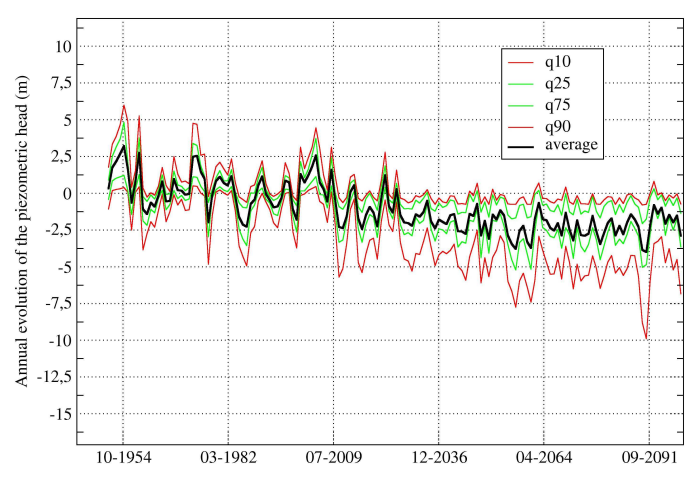

MODCOU_SOMME

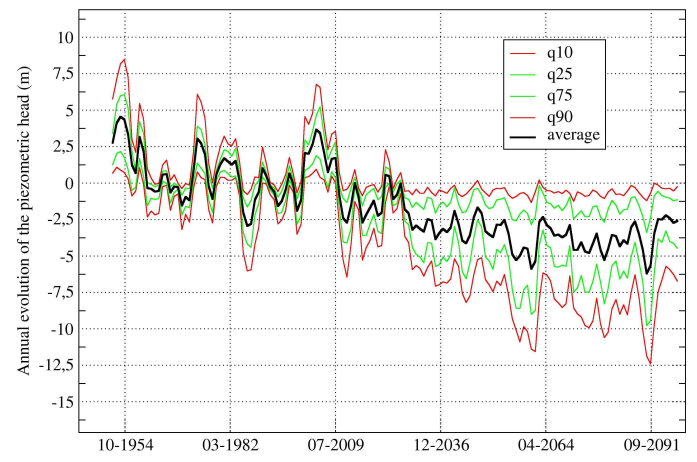

MODCOU_SEINE

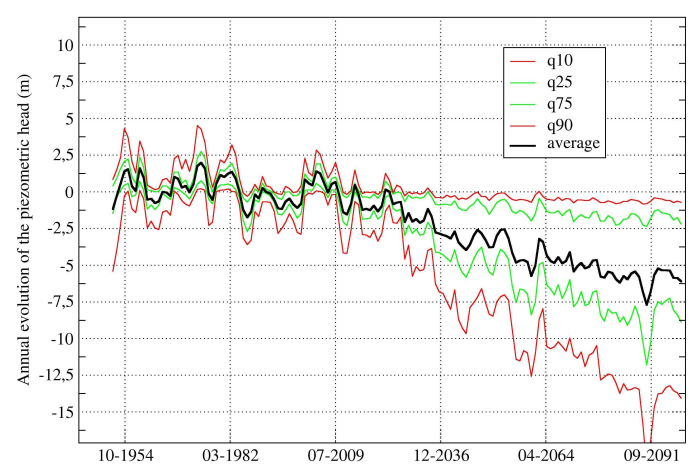

MARTHE_SOMME

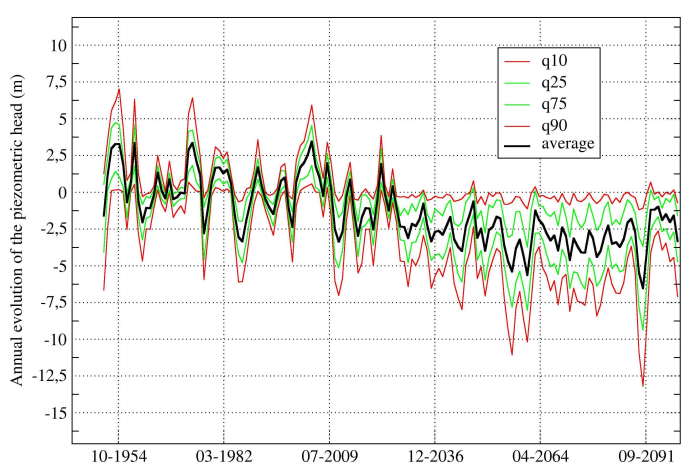

SIM_SOMME

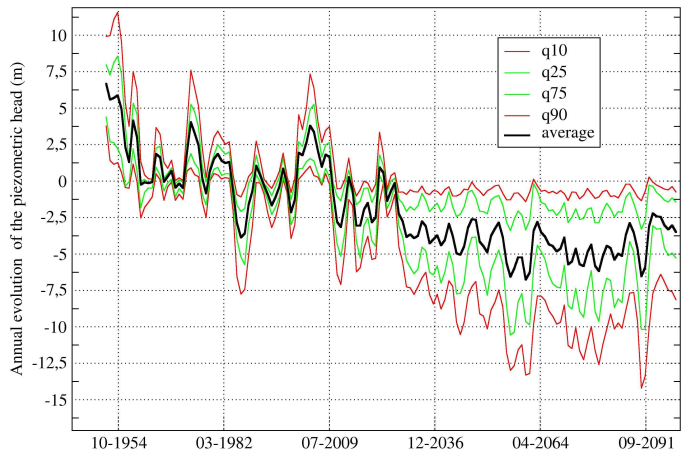

SIM_SEINE

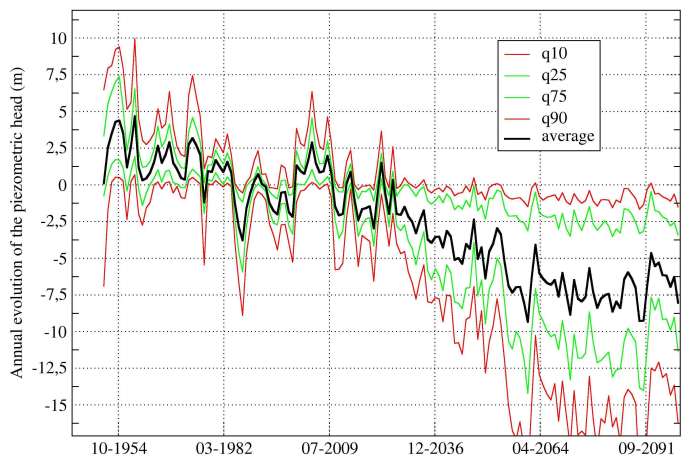

Figure 9 Annual evolution of the piezometric heads (m) projected on the Somme and Seine basins by the hydrological models for the $1 \mathrm{~W}$ continuous DCP, in comparison with the average 19712000 period. The average over the simulated wells is plotted in thick black lines, the quantiles 10 and 90 are plotted in red, and the quantiles 25 and 75 in green. 


\section{Online resource 5}

\section{Impact of climate change on the hydrogeology of two basins in Northern France}

Florence Habets ${ }^{1,2}$, Julien Boé ${ }^{3}$, Michel Déqué ${ }^{4}$, Agnès Ducharne ${ }^{1}$, Simon Gascoin ${ }^{5}$, Ali Hachour ${ }^{2}$, Eric Martin ${ }^{4}$, Christian Pagé ${ }^{5}$, Eric Sauquet ${ }^{6}$, Laurent Terray ${ }^{3}$, Dominique Thiéry $^{7}$, Ludovic Oudin ${ }^{1}$, Pascal Viennot ${ }^{2}$,

${ }^{1}$ UMR Sisyphe 7619, UPMC, CNRS, Paris, France

${ }^{2}$ Centre de Géosciences Mines Paristech, Fontainebleau, France

${ }^{3}$ CERFACS CNRS, Toulouse, France

${ }^{4}$ CNRM/GAME (Météo-France, CNRS), Toulouse, France

${ }^{5}$ CESBIO, Toulouse, France

${ }^{6}$ IRSTEA, Lyon, France

${ }^{7}$ BRGM, Orléans, France

Corresponding author: Florence.Habets@mines-paristech.fr

\section{Uncertainty analysis}

In order to understand its origin, an analysis of the uncertainty was made by investigating the variance associated with the various sources, i.e. the climate modelling, the hydrological modelling, the emission scenario, and the downscaling methods. To do this, we focused on a variable encompassing the characteristics of the basins: the evolution of the discharge at the outlets. To perform such analysis it is necessary to use a homogeneous set of impact projections, and we used the method of Kendall and Stuart (1977) described in Déqué et al. (2007) to reconstruct the missing values. To avoid using a sparse matrix, as only one climate model was downscaled by several methods and using two different emission scenarios the analysis was made in three parts: first, an analysis of the results using the seven climate projections based on the A1B emission scenario and downscaled by the WT method, which allowed us to study the uncertainty associated with the hydrological and climate modelling in the two periods of interest (Table 6), then an analysis of the results using a given climate model (ARPEGE-V4 in 2080), but with two different emission scenarios and three downscaling methods (Table 7) and finally, an analysis of the results in 2080 with all climate models, hydrological models, downscaling methods and emissions scenarios (Table 3). In this way, the two first matrices used to compute 
the variance were almost complete, and the statistical method applied to fill the matrix had a smaller impact. For instance, in Table 6, there are only two components: the hydrological models and the climate models (noted with indices $i$ and $\mathrm{j}$ respectively). The total variance in the case of Table 6 is given by:

$V=H+G+H G$

eq1

with

$H=\sum_{i=1, n b_{-} h y d r o}(X(i .)-X(. .))^{2}$
$G=\sum_{j=1, n b_{-} \text {proj }}(X(. j)-X(. .))^{2}$

eq2

eq3

and

$H G=\sum_{i=1, n b_{-} h y d r o} \sum_{g=1, n b_{-} p r o j}(X(i j)-X(i .)-X(. j)+X(. .))^{2} \quad$ eq4

where $\mathrm{X}(.$.$) is the average of the evolution for each hydrological model and each$ climate model, $\mathrm{X}(\mathrm{i}$.$) is the average of the evolution of the hydrological model \mathrm{i}$ for each climate model, nb_hydro is the number of hydrological models, and nb_proj is the number of downscaled climate projections.

This method estimates missing values, using the approximation:

$$
X(i j)=X(i .)+X(. j)-X(. .)
$$

In such cases, the variance associated with the hydrological model is expressed as $V(H)=H+H G$ and the sum $\mathrm{V}(\mathrm{H})+\mathrm{V}(\mathrm{G})$ thus exceeds $100 \%$.

The evolution of the discharge computed with the A1B projections with the full matrix (without missing values) shows a rather large decrease of the river discharge (-14 and $-18 \%$ in 2050, -24 and $-22 \%$ in 2080 for the Seine and Somme basins respectively) but with an uncertainty, expressed by the standard deviation, that is about as large (Table 6). The discharge decrease is more pronounced when the same estimation is made using the ARPEGE-V4 projections with different emission scenarios and downscaling methods (-34 and $-40 \%$ in 2080 for the Seine and Somme basins, Table 7) but the standard deviation is reduced, which reinforces the signal of a marked decrease in the discharge.

Without considering the results of CLSM, Table 6 shows that the main source of uncertainty is clearly the climate models for all basins and periods, although it is 
not strongly dominant for the Seine in 2080. Table 7 shows that the uncertainties associated with the downscaling methods and the emission scenarios are of the same order as that associated with the hydrological models, and are even higher in the Somme basin. The consideration of the four sources of uncertainty in 2080, although involving the use of a sparse matrix, provides results that are in between the two previous estimations (Table 3). The variances obtained confirm that the uncertainty on the climate models dominates, with a total variance about three times above the other ones, the three other sources of uncertainty being of the same order of magnitude, at least as regards the impact on the evolution of the annual discharge.

It can be seen in the tables that quite different conclusions would be reached if the CLSM projections were taken into account, as the impact of the uncertainty associated with hydrological modelling would then be greater.

\section{References:}

Déqué M, Rowel DP, Lüthi D, Giorgi F, Christensen JH, Rockel B, Jacob D, Kjellström E, de Castro M, van den Hurk B (2007) An intercomparison of regional climate simulations for Europe: assessing uncertainties in model projections. Climatic Change 81:53-70

Kendall M, Stuart A, Ord JK (1977) The advanced theory of statistics. Vol 3: design and analysis, and time series, 4th edition, Charles Griffin and Co Ltd, $780 \mathrm{pp}$ 


\begin{tabular}{|c|c|c|c|c|}
\hline \multirow[t]{2}{*}{ Type } & \multicolumn{2}{|c|}{ Seine at Poses Qobs $=538 \mathrm{~m}^{3} / \mathrm{s}$} & \multicolumn{2}{|c|}{$\begin{array}{l}\text { Somme at } \\
\text { Qobs }=34.9 \mathrm{~m}^{3} / \mathrm{s}\end{array}$} \\
\hline & All & All but CLSM & All & All but CLSM \\
\hline \multicolumn{5}{|c|}{2050} \\
\hline Missing values & 3 (out of 35$)$ & 2 (out of 28$)$ & 15 (out of 42 ) & 9 (out of 35$)$ \\
\hline $\mathrm{V}(\mathrm{H})$ & 59 & 27 & 88 & 29 \\
\hline $\mathrm{V}(\mathrm{G})$ & 47 & 77 & 13 & 77 \\
\hline Evolution & $-99+/-68$ & $-76+/-54$ & $-11+/-10$ & $-7+/-4$ \\
\hline \multicolumn{5}{|c|}{2080} \\
\hline Missing Values & 7 (out of 35) & 6 (out of 28$)$ & 19 (out of 42 ) & 13 (out of 35) \\
\hline $\mathrm{V}(\mathrm{H})$ & 51 & 43 & 84 & 21 \\
\hline $\mathrm{V}(\mathrm{G})$ & 51 & 58 & 16 & 82 \\
\hline Evolution & $-157+/-102$ & $-133+/-90$ & $-12+/-12$ & $-8+/-5$ \\
\hline
\end{tabular}

Table 6 Uncertainty analysis of the impact of climate change on the discharge at the outlets of the Seine and Somme basins around 2050 and 2080 for the hydrological projection using the A1B climate model downscaled by the WT method: number of missing values reconstructed by the statistical method, variance $(\%)$ associated with the uncertainty of the hydrological model $(\mathrm{V}(\mathrm{H}))$ and the GCM $\left(\mathrm{V}(\mathrm{G})\right.$, and evolution of the annual discharge expressed in $\mathrm{m}^{3} / \mathrm{s}$. 


\begin{tabular}{|l|l|l|l|l|}
\hline \multirow{2}{*}{ Type } & \multicolumn{2}{|l|}{ Seine at Poses Qobs $=538 \mathrm{~m}^{3} / \mathrm{s}$} & \multicolumn{2}{l|}{$\begin{array}{l}\text { Somme at Abbeville } \\
\text { Qobs }=34.9 \mathrm{~m}^{3} / \mathrm{s}\end{array}$} \\
\cline { 2 - 6 } & All & All but CLSM & All & All but CLSM \\
\hline Missing values & 7 (out of 30) & 4 (out of 24) & 12 (out of 36) & 8 (out of 30) \\
\hline V(H) & 91 & 53 & 91 & 30 \\
\hline V(DM) & 10 & 43 & 8 & 62 \\
\hline V(SRES) & 11 & 38 & 11 & 68 \\
\hline Evolution & $-219+/-82$ & $-183+/-40$ & $-18+/-10$ & $-14+/-3$ \\
\hline
\end{tabular}

Table 7 Uncertainty analysis of the impact of climate change on the discharge at the outlets of the Seine and Somme basins around 2080 for the hydrological projections made with the ARPEGE climate model under SRES A1B and A2 scenarios, and downscaled by the WT, AN and QQ methods: number of missing values that were reconstructed by the statistical method, variance (\%) associated with the uncertainty of the hydrological model $(\mathrm{V}(\mathrm{H}))$, the downscaling method $(\mathrm{V}(\mathrm{DM}))$ and the emission scenario (V(SRES)), and evolution of the annual discharge expressed in $\mathrm{m} 3 / \mathrm{s}$ 


\begin{tabular}{|c|c|c|c|c|}
\hline \multirow[t]{2}{*}{ Type } & \multicolumn{2}{|c|}{ Seine at Poses Qobs $=538 \mathrm{~m}^{3} / \mathrm{s}$} & \multicolumn{2}{|c|}{$\begin{array}{l}\text { Somme at Abbeville } \\
\text { Qobs }=34.9 \mathrm{~m}^{3} / \mathrm{s}\end{array}$} \\
\hline & All & All but CLSM & All & All but CLSM \\
\hline Missing values & $\begin{array}{l}163 \text { (out of } \\
210)\end{array}$ & $\begin{array}{ll}130 & \text { (out of } \\
168) & \end{array}$ & $\begin{array}{ll}210 & \text { (out of } \\
252) & \end{array}$ & $\begin{array}{ll}170 \quad \text { (out of } \\
210)\end{array}$ \\
\hline $\mathrm{V}(\mathrm{G})$ & 45 & 69 & 39 & 82 \\
\hline $\mathrm{V}(\mathrm{H})$ & 48 & 18 & 64 & 25 \\
\hline $\mathrm{V}(\mathrm{DM})$ & 11 & 14 & 7 & 16 \\
\hline $\mathrm{V}(\mathrm{SRES})$ & 9 & 15 & 9 & 15 \\
\hline Evolution & $-186+/-107$ & $-155+/-81$ & $-14+/-13$ & $-11+/-9$ \\
\hline
\end{tabular}

Table 3 Same as Table 2 but with all the climate runs. $V(G)$ is the variance associated to the climate runs. 